Review

\title{
Structure and Function of Filamin $C$ in the Muscle Z-Disc
}

\author{
Zhenfeng Mao and Fumihiko Nakamura *D \\ School of Pharmaceutical Science and Technology, Tianjin University, Tianjin 300072, China; \\ zhenfengmao@tju.edu.cn \\ * Correspondence: fnakamura@tju.edu.cn
}

Received: 17 March 2020; Accepted: 9 April 2020; Published: 13 April 2020

\begin{abstract}
Filamin C (FLNC) is one of three filamin proteins (Filamin A (FLNA), Filamin B (FLNB), and FLNC) that cross-link actin filaments and interact with numerous binding partners. FLNC consists of a N-terminal actin-binding domain followed by 24 immunoglobulin-like repeats with two intervening calpain-sensitive hinges separating R15 and R16 (hinge 1) and R23 and R24 (hinge-2). The FLNC subunit is dimerized through R24 and calpain cleaves off the dimerization domain to regulate mobility of the FLNC subunit. FLNC is localized in the Z-disc due to the unique insertion of 82 amino acid residues in repeat 20 and necessary for normal Z-disc formation that connect sarcomeres. Since phosphorylation of FLNC by PKC diminishes the calpain sensitivity, assembly, and disassembly of the Z-disc may be regulated by phosphorylation of FLNC. Mutations of FLNC result in cardiomyopathy and muscle weakness. Although this review will focus on the current understanding of FLNC structure and functions in muscle, we will also discuss other filamins because they share high sequence similarity and are better characterized. We will also discuss a possible role of FLNC as a mechanosensor during muscle contraction.
\end{abstract}

Keywords: Filamin C; FLNC; sarcomere; Z-disc; mutation; filaminopathy; myopathy

\section{Introduction}

Filamin C (FLNC) protein is one of three filamin isoforms (A, B, C) that cross-link actin filaments (F-actin) and interact with various binding partners [1,2]. Although Filamin A (FLNA) and Filamin B (FLNB) are ubiquitously expressed [3], FLNC is most prevalent in skeletal and cardiac muscles and localizes to Z-discs, myotendinous junctions, the sarcolemma and intercalated discs [4-7]. However, FLNC is detectable in many tissues and tissue culture cells other than heart and skeletal muscle $[4,8]$. In this review, we will focus on the structure and functions of FLNC in normal and patho-physiology, but we will also discuss other filamins because they have high homology $(>70 \%)$ and both common and isoform-distinct functionalities [2,9]. However, expression of FLNA and FLNB are not detected in the Z-disc of developed skeletal and cardiac muscles $[7,10,11]$. Instead, FLNA and FLNB are concentrated in vascular endothelial cells $[10,12]$, although low expression of FLNB is detected in skeletal muscle (https://www.proteinatlas.org/ENSG00000136068-FLNB/tissue/skeletal+muscle).

The importance of the FLNC gene was highlighted when it was found to be associated with myofibrillar myopathy in skeletal and cardiac muscles [13-16]. This review will integrate contemporary data based on disease phenotypes, DNA sequencing, and biochemical and cell biological studies of FLNC protein to discuss common and distinct disease mechanisms.

Recent research revealed that FLNA mediates mechano-sensing and mechano-transduction and FLNC may also participate in mechano-transduction [2,17-19]. Therefore, this review will discuss how FLNC and FLNA may similarly and differently mediate mechanotransduction. 


\section{Structure of Filamin C (FLNC) and Its Family Proteins}

The human FLNC gene is encoded in chromosome 7q32.1, comprising $29.5 \mathrm{~kb}$ of genomic DNA and containing 48 coding exons $[3-5,20,21]$. Sequence alignment revealed that FLNC protein is very similar to other filamins (72.8\% to FLNA, $71.2 \%$ to FLNB) that consist of N-terminal spectrin related actin-binding domain (srABD) followed by 24 immunoglobulin (Ig)-like repeats (R1-24) with two intervening calpain-sensitive hinges separating R15 and R16 (hinge 1) and R23 and R24 (hinge-2) (Figure 1). However, FLNC contains an insertion of 82 amino acids in R20 and hinge- 1 is spliced out during myogenesis [5,22]. In fact, the splice variant that is predominantly expressed in skeletal and cardiac muscles lacks exon 32 that encodes the hing-1, resulting in a protein of 2692 amino acids [4]. The hinge- 1 of FLNB is also removed during myogenesis but not in FLNA [22]. Although the structure of FLNC strand A is not known (strand A of FLNC R16 in PDB:2D7N is missing), it is likely that FLNC strand A is free from the folded structure because strand A of R16 of FLNA and FLNB are not folded (PDB: 2K7P and 2EE9) and their sequences are similar to that of FLNC. Therefore, some flexibility between R15 and R16 could be retained without hinge-1. Interestingly, the splicing of the hinge- 1 is correlated with switching of integrin expression from $\beta 1 \mathrm{~A}$ to $\beta 1 \mathrm{D}$ during myogenesis in mouse $\mathrm{C} 2 \mathrm{C} 12$ myoblast [22].

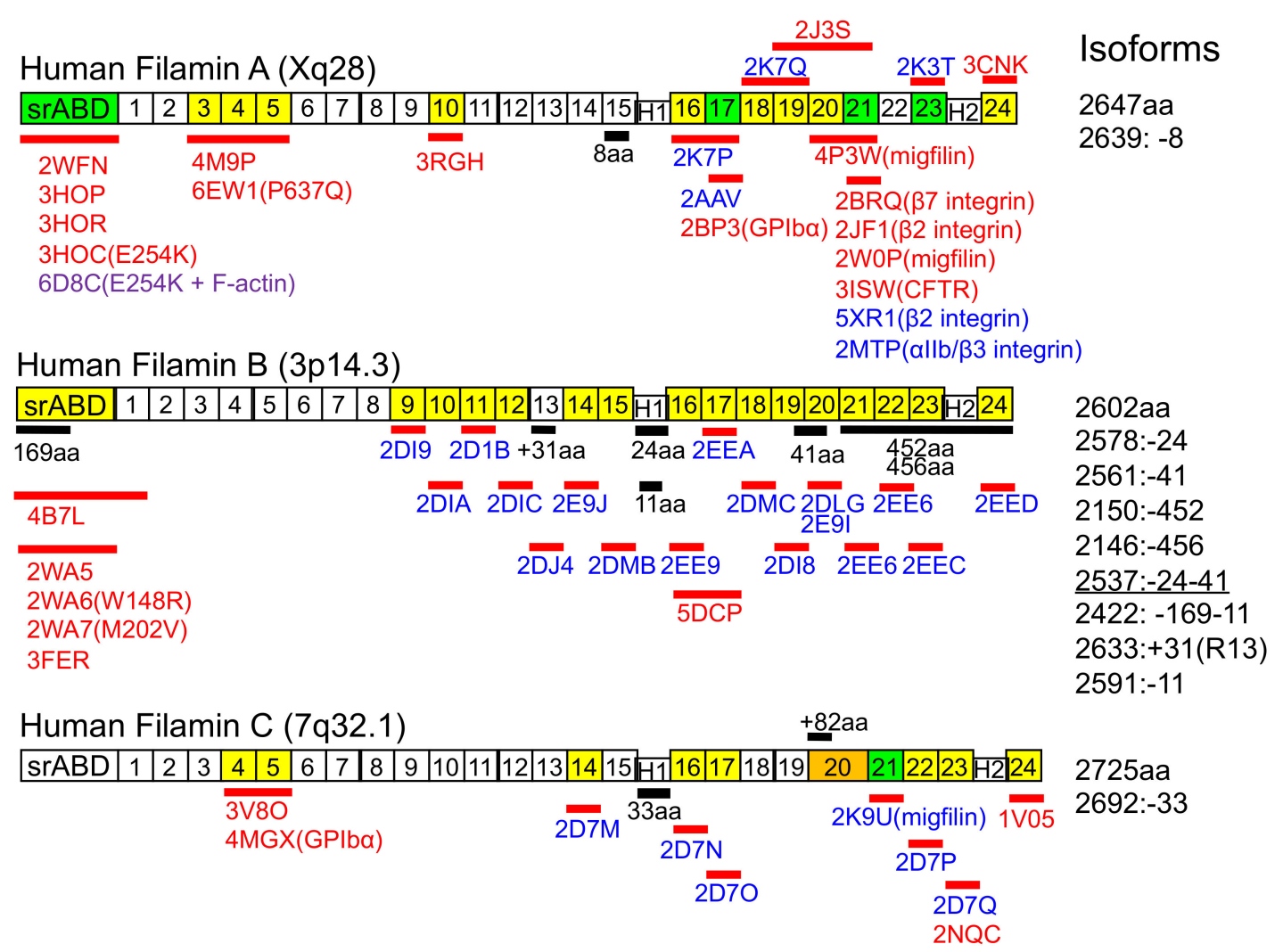

Figure 1. Schematic structures of human filamins (FLNs). All three FLNs consist of an N-terminal spectrin-related actin-binding domain (srABD) followed by 24 Ig-like repeats with two intervening calpain-sensitive hinges. Black bars indicate unique amino acid residues in each isoform. Solved domain structures are indicated in red bars with PDB accession numbers in red (X-ray crystallography), blue (NMR), and purple (cryo-EM). Green indicates a domain whose structure is solved as a complex with a binding partner. Yellow indicates a domain whose structure is solved. srABD, spectrin-related actin-binding domain; $\mathrm{H} 1$, hinge-1: $\mathrm{H} 2$, hinge-2. Note that the figure indicates the embryonic forms of Filamin C (FLNC) and that hinge-1 of FLNC is spliced out during myogenesis.

The splice variant without hinge- 1 is also expressed in other tissue such as bone marrow and thyroid, but a biological significance of the splicing is not known [4]. Because purified FLNC protein 
is not available, biochemical and biophysical properties of full-length FLNC have not been studied. Nevertheless, it is likely that FLNC has similar functions according to the sequence similarity to FLNA and B. Therefore, we briefly describe the structure of FLNA which is better characterized than other filamins. Detailed reviews of FLNA structure are available in other journals $[2,18]$. The N-terminal srABD consists of two calponin homology domains $(\mathrm{CH} 1$ and $\mathrm{CH} 2)$ that are found in many other actin-binding proteins [23]. Although the atomic structure of FLNC srABD is not available, its sequence similarity to the srABD of FLNA and B is over $90 \%$. Their differences are concentrated in the very $\mathrm{N}$-terminal sequences before $\mathrm{CH} 1$ and the linker between $\mathrm{CH} 1$ and $\mathrm{CH} 2$ [24]. Currently the biological significance of these differences is not known.

Atomic structures of the individual Ig repeats have been determined by Nuclear Magnetic Resonance (NMR) analysis and X-ray crystallography as summarized in Figure 1. The Ig domains are composed of seven strands (A through G). Although the repeats were predicted to be linearly aligned to form rods (rod-1, R1-R15; rod-2, R16-R23, Figure 2) based on the V-shaped structure of the purified FLNA molecule [25], structural analysis of the shorter fragments of the rods revealed domain-domain pairs in R3-R5, R16-R17, R18-R19, and R20-R21 [26-29] (Figure 2). Small-angle X-ray scattering revealed a compact structure in FLNC R3-R5 and possibly in R11-R12 and R14-R15 [29,30]. These domain pairs can be unfolded by mechanical forces to expose cryptic binding site as discussed below (mechanotransduction). Interestingly, all currently reported structures of filamin-partner complexes demonstrated that these binding partners interact through the cleft formed by $C$ and $D$ strands, which is blocked in some domain pairs [2,18] (Figure 2). However, effect of the insertion of 82 amino acids in $\mathrm{R} 20$ on the domain pair of R20-R21 is not known. In addition, loss of hinge- 1 and insertion of 82 amino acids in R20 of FLNC would influence the structure of full-length FLNC molecule but purified FLNC molecule is currently not available to investigate. Such a unique structure of FLNC, if any, could determine the function of FLNC in muscle Z-disc.

A

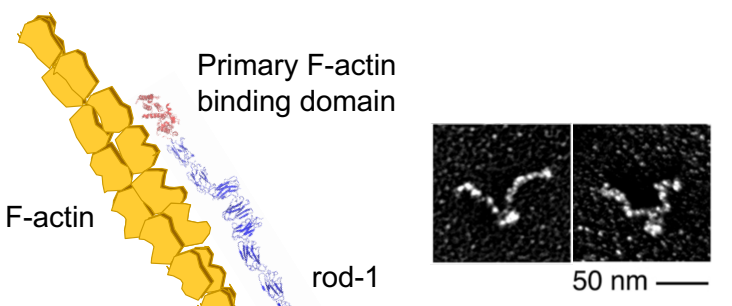

B
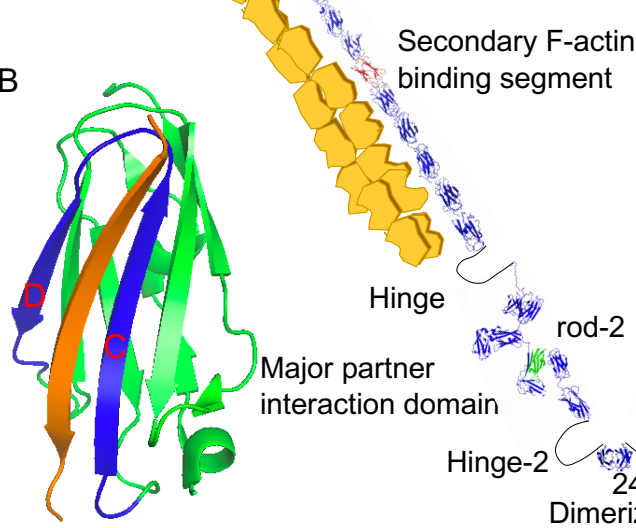

The
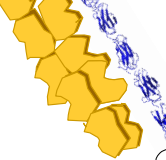

Hinge

Major partner
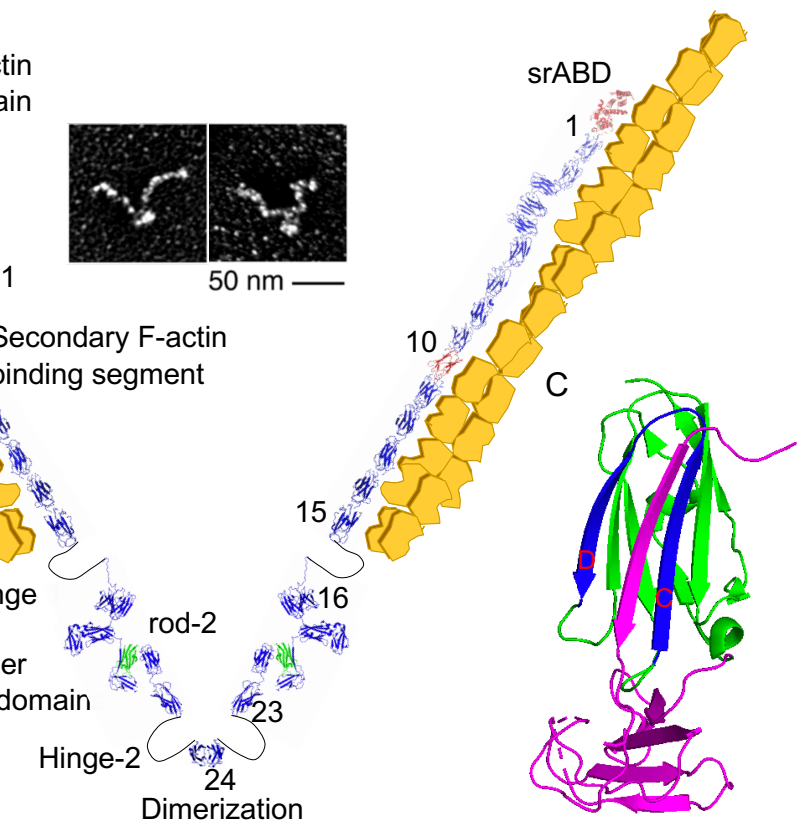

Figure 2. Current atomic structure of Filamin A (FLNA) cross-linking F-actin. (A) FLNA is a $560 \mathrm{kDa}$ dimer having spectrin-related actin-binding domain (srABD) followed by 24 Ig-like repeats. Repeats highlighted in red bind along F-actin (yellow). The green labeled domain (R21) is the cryptic integrin binding domain. (B) Structure of R21 complexed with cytoplasmic domain of integrin beta7 (orange). All the FLNA-partner complexes that have been structurally revealed use the cleft formed by C and D strands indicated in blue. (C) Structure of domain pairs of R20-R21. Note that the CD cleft are blocked by strand A of R20 (magenta). 
FLNA possesses the secondary F-actin binding site in rod-1, and R10 alone can decorate purified F-actin [31]. Although the srABD is necessary and sufficient for F-actin binding, the secondary ABD on rod-1 is necessary for high-avidity F-actin binding [27]. The R10 of FLNC shares high sequence similarity with that of FLNA ( $86 \%$ homology), but F-actin binding activity of FLNC R10 has never been examined.

The last repeat, R24, of FLNA is sufficient to form an L-shaped homodimer [27], but biochemical and yeast two hybrid analysis demonstrated that heterodimerization between different filamin isoforms is possible [32,33]. This could be a reason why FLNB occasionally localized at the Z-discs in cultured C2C12 myoblasts by forming a heterodimer with FLNC [22]. It is also possible that dimerization or even oligomerization of filamin subunits are mediated by their binding partners which are dimerized or oligomerized [34].

\section{FLNC Binding Partners}

In 2011, we listed over 90 filamin binding partners including channels, receptors, intracellular signaling molecules, and even transcription factor [2]. In the past ten years, the list of filamin binding partners has been expanded and is still expanding [35,36]. Considering the sequence similarity of filamin isoforms, FLNC likely interacts with most of these numerous binding partners if they are co-expressed, although one binding partners has been shown to only interact with filamin A [37]. Here, we focused on summarizing binding partners that were experimentally demonstrated to interact with FLNC in Table 1 with known functions. Importantly, mutations in many of these binding partners such as myotilin, titin, and BAG3 also leads to myofibrillar myopathies that are associated with disintegration of the Z-disc [38]. Although some of these binding partners interact with all filamin isoforms, others may specifically interact with FLNC. For example, muscle specific myotilin interacts with FLNC through the insertion of 82 amino acid residues in R20, which is missing in FLNA and $\mathrm{B}[7,39]$. Despite numerous lists of the binding partners, atomic structures of many of their complexes with FLNC have remained uncharacterized so far (Figure 1). Not many experiments have been performed regarding the function of their interaction. Because deletion of one of the components for functional analysis most likely does not unveil the specific function of their interaction, more pinpoint intervention is necessary without disturbing other functions.

\section{Topology of FLNC in the Z-Disc}

FLNC localizes to Z-discs, myotendinous junctions, the sarcolemma, and intercalated discs of striated muscle [6]. In the Z-disc, FLNC interacts with the calsarcins (FATZs, myozenins) [40-42], myotilin [7] and myopodin [43], while at the sarcolemma FLNC directly binds $\gamma$ - and $\delta$-sarcoglycans [5] as well as ponsin/CAP [44]. FLNC also interacts with XIRP family proteins (Xin and XIRP2) [45,46]. In adult muscle, XIRPs not only colocalize with FLNC at myotendinous junctions of skeletal muscles and intercalated discs of cardiomyocytes, but also at sites of small injuries and remodeling $[47,48]$ resulting from exercise and eccentric contractions [49-51]. Consistent with these results, loss of FLNC in mice causes a severe muscle phenotype that includes defects in embryonic myogenesis resulting in a decreased number of primary fibers, excessive fiber size variation, and a disturbance of sarcomere architecture [52].

Ultrastructure of skeletal and cardiac muscle displays a striated sarcomeric pattern with 2.0 5.0 $\mu \mathrm{m}$ of sarcomeres which are connected through the Z-disc [53-56] (Figure 3A). The width of the Z-disc differs in different muscle: fast fibers, $\sim 30-50 \mathrm{~nm}$; slow and cardiac fibers, $\sim 100 \mathrm{~nm}$, being determined by the amount of overlap of F-actin and by the number of Z-link layers ranging from two in fast muscle to six in slow muscle [57]. Histochemical study detects FLNC protein exclusively in the Z-disc despite its binding ability to F-actin that is also expressed in other regions of sarcomere [5,7]. Such specificity is defined by FLNC-binding proteins localized in the Z-disc. As listed in Table 1, several Z-disc specific proteins interact with FLNC. For example, myotilin interacts with FLNC through the unique insertion in R20 and FLNA, which does not contain this insertion, and does not localize in the 
Z-disc upon overexpression in muscle cells [7]. During muscle development, FLNC mRNA and protein are absent from proliferating cultured human skeletal muscle cells, but up-regulated immediately after the induction of differentiation [6]. Since FLNC localizes in the Z-disc already at the first stages of Z-disc formation, FLNC might play a role in Z-disc assembly.

Figure 3B-E shows possible models of how FLNC cross-links F-actin in the Z-disc. Actin filaments are oriented with their plus ends in the Z-discs and their minus ends toward the center of the sarcomere. Although FLNA rod-1 domain interacts with F-actin [27,31], it is not known if FLNC rod-1 also interacts with F-actin. If binding of FLNC to F-actin has orientation selectivity, model B and C are not possible. Because the length of FLNA subunit is $\sim 80 \mathrm{~nm}$ [27] and FLNC has also 24 repeats, and because both of the two FLNC subunits have binding sites for Z-disc proteins such as titin and myotilin, the width of the Z-disc should be wider in model D and F unless one of the FLNC subunit is located outside of the Z-disc detected by electronmicroscopy. Therefore, it is likely that FLNC connects F-actin in model B or $\mathrm{C}$.

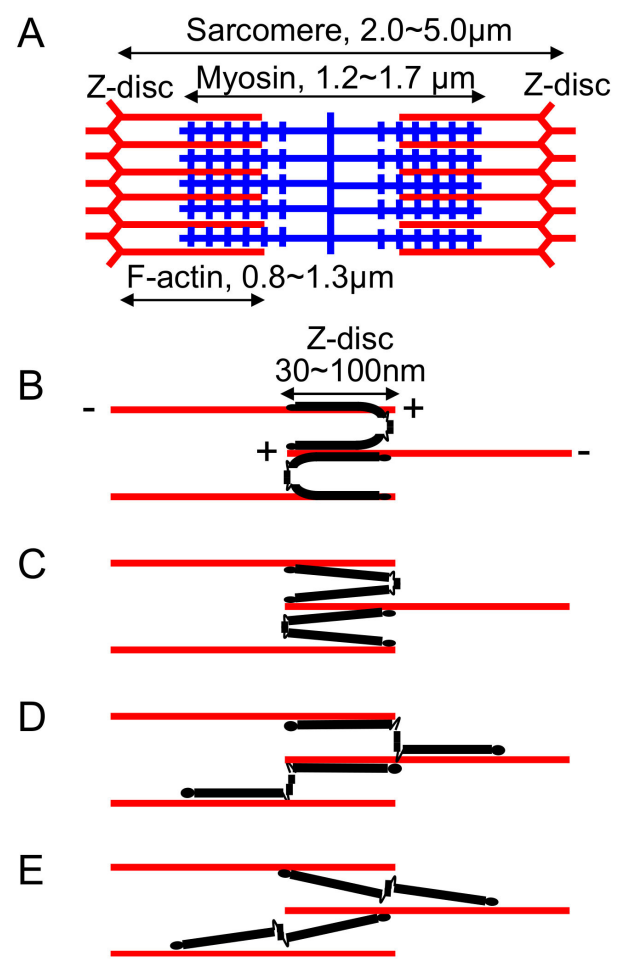

Figure 3. Schematic structure of muscle sarcomere and how FLN connects F-actin in the Z-disc. (A) Sarcomere units in striated muscle. The width of the Z-disc: fast fibers, 30-50 nm; slow and cardiac fibers, 100 nm. (B-E) A model of how FLNC (black) cross-links F-actin (red) in the Z-disc. Actin filaments are oriented with their plus ends in the Z-discs and their minus ends toward the center of the sarcomere. Because FLNC also interacts with transmembrane proteins such as integrins and sarcoglycans [58] (Table 1), such connections could also determine topology of FLNC and its binding proteins in the Z-disc. However, since FLNC is highly dynamic in the Z-disc, it is likely that such structure is constantly remodeled which may play a role in the fast repair of myofibrillar microdamage [59]. 
Table 1. FLNC binding partners.

\begin{tabular}{|c|c|c|c|}
\hline Binding Partner & $\begin{array}{l}\text { Binding Domain } \\
\text { on FLNC }\end{array}$ & Function & Reference \\
\hline HSPB1(HSP27) & R18-21 & $\begin{array}{l}\text { HspB1, an abundant molecular chaperone and FLNC form a } \\
\text { complex. Phosphorylation of HspB1 facilitates extension of } \\
\text { FLNC being localized to load-bearing sites. }\end{array}$ & [60] \\
\hline $\begin{array}{l}\text { MEK1/2 } \\
\text { ERK1/2 }\end{array}$ & Co-IP & $\begin{array}{l}\text { FLNC enhances the mitogen-activated protein kinase } \\
\text { signaling pathway during tumorigenesis. }\end{array}$ & [61] \\
\hline Klhl31 & Co-IP & Klhl31 targets Flnc for ubiquitination and degradation. & [62] \\
\hline HSPB7 & $\mathrm{R} 24$ & $\begin{array}{l}\text { Aggregation and mislocalization of FLNC occur in the muscle } \\
\text { by loss of HspB7, leading to myopathy. }\end{array}$ & [63] \\
\hline KCNE2 & $\mathrm{Y} 2 \mathrm{H}, \mathrm{Co}-\mathrm{IP}$ & $\begin{array}{l}\text { FLNC and KCNE2, potassium voltage-gated channel, } \\
\text { co-localized within the cell, however, a physical interaction } \\
\text { was only observed under hypoxic conditions. }\end{array}$ & [64] \\
\hline$\alpha 2 \mathrm{C}$-adrenoceptors & $\begin{array}{l}1979 \text { and } 2206 \\
\text { (R18-R20) } \\
\text { In silico modeling }\end{array}$ & $\begin{array}{l}\text { Phylogenetic and sequence analysis showed that these } \\
\text { interactions have evolved in warm-blooded animals. }\end{array}$ & [65] \\
\hline Aciculin & $\begin{array}{c}\text { Co-IP, } \\
\text { SPR (R18-21) }\end{array}$ & $\begin{array}{l}\text { Dystrophin-binding protein aciculin interacts FLNC and Xin } \\
\text { in Z-line. }\end{array}$ & [66] \\
\hline Fbxl22 & Co-IP & FLNC is ubiquitinated in Fbxl22-dependent fashion. & [67] \\
\hline Ankyrins-G & R5-6 & $\begin{array}{l}\text { Ankyrins-G contains the muscle-specific } \\
\text { Obscurin/Titin-Binding-related Domain that binds to FLNC } \\
\text { and plectin. }\end{array}$ & [68] \\
\hline $\begin{array}{c}\text { Myopodin } \\
\text { (synaptopodin2) }\end{array}$ & $\mathrm{R} 20-21$ & $\begin{array}{l}\text { Myopodin also interacts with other Z-line proteins such as } \\
\text { alpha-actinin and zyxin. The interaction might play a role in } \\
\text { early assembly and stabilization of the Z-disc. }\end{array}$ & [43] \\
\hline IGFN1 & R19-24 (Y2H) & FLNC interacts IGFN1 and KY at Z-line & [69] \\
\hline $\begin{array}{l}\text { MKK4 } \\
\text { MKK7 }\end{array}$ & Co-IP & $\begin{array}{l}\text { MKK4 and MKK7 bind all FLNs. FLNA enhances the } \\
\text { activation of MKK7 and JNK. }\end{array}$ & [70] \\
\hline BAG3 & Co-localization & $\begin{array}{l}\text { BAG-3 stimulates the release of filamin from a cytoskeleton. } \\
\text { Released filamin could subsequently be ubiquitylated by the } \\
\text { CHIP/UbcH5 conjugation machinery in the presence of the E1 } \\
\text { ubiquitin-activating enzyme. } \\
\text { FLNC }{ }^{\mathrm{W} 2710 \mathrm{x}} \text { blocks BAG3 mediated clearance of protein } \\
\text { aggregates. }\end{array}$ & {$[14,71]$} \\
\hline $\begin{array}{l}\text { CAP (SORBS1, } \\
\text { Ponsin) }\end{array}$ & $\mathrm{R} 2$ & $\begin{array}{l}\text { Cbl-associated protein (CAP) is enriched in oxidative muscle } \\
\text { fiber. When overexpressed, CAP recruits FLNC to } \\
\text { cell-extracellular matrix adhesions and inhibits FLNC-induced } \\
\text { cell spreading on fibronectin. }\end{array}$ & {$[44]$} \\
\hline USP25m & $\mathrm{Y} 2 \mathrm{H}$ & $\begin{array}{l}\text { The ubiquitin-specific protease USP25 interacts with three } \\
\text { sarcomeric proteins. }\end{array}$ & {$[72]$} \\
\hline Titin & R20-R24 (Y2H) & $\begin{array}{c}\text { Titin Z2-Zis1 domain interacts FLNA/C, alpha-actinin, and } \\
\text { nabulin. }\end{array}$ & [73] \\
\hline Calpain 1 & R23-R24 & $\begin{array}{l}\text { Calpain } 1 \text { cleaves FLNC hinge-2. Phosphorylation of FLNC by } \\
\text { PKC alpha protects the proteolysis of FLNC by calpain } 1 \text {. }\end{array}$ & [74] \\
\hline Xin (XIRP1, 2) & $\mathrm{R} 20(\mathrm{Y} 2 \mathrm{H})$ & $\begin{array}{l}\text { Xin isoforms associate differentially with FLNC. } \\
\text { XinB and FLNC compete for binding to aciculin and no } \\
\text { ternary complex is formed. }\end{array}$ & {$[45,66]$} \\
\hline$\beta$-arrestin2 & $\mathrm{R} 22(\mathrm{Y} 2 \mathrm{H})$ & $\begin{array}{c}\text { The interaction might regulate dopamine D3 receptor } \\
\text { signaling. }\end{array}$ & [75] \\
\hline RasGAP & R15-R17 & $\begin{array}{c}\text { Disrupting the RasGAP-filamin pathway results in reduced } \\
\text { myocyte growth. }\end{array}$ & [76] \\
\hline Integrin beta1A & R20 (Y2H) & & [39] \\
\hline
\end{tabular}


Table 1. Cont.

\begin{tabular}{|c|c|c|c|}
\hline Binding Partner & $\begin{array}{l}\text { Binding Domain } \\
\text { on FLNC }\end{array}$ & Function & Reference \\
\hline PKBalpha & substrate & $\begin{array}{l}\text { PKBalpha phosphoarylate FLNC Ser2213, which lies in an } \\
\text { insert not present in the FLNA and FLNB isoforms. } \\
\text { Insulin also induced the phosphorylation of FLNC at Ser2213 } \\
\text { in cardiac muscle in vivo }\end{array}$ & [77] \\
\hline KY protein & R20-R22 (Y2H) & $\begin{array}{l}\text { KY protein cleaves FLNC. Mutation of KY protein disrupts } \\
\text { normal distribution of FLNC. }\end{array}$ & [78] \\
\hline $\begin{array}{l}\text { alpha1-adrenergic } \\
\text { receptor }\end{array}$ & $\mathrm{Y} 2 \mathrm{H}$ & Biological significance of the interaction is not known. & [79] \\
\hline Calpain 3 & substrate & $\begin{array}{l}\text { FLNC after C3 cleavage, abolishes this interaction with the } \\
\text { sarcoglycans. }\end{array}$ & {$[80]$} \\
\hline N-RAP & R20-24 (Y2H) & $\begin{array}{l}\text { During myofibril assembly in cultured chick cardiomyocytes, } \\
\text { N-RAP, and filamin appear to co-localize with alpha-actinin in } \\
\text { the earliest myofibril precursors found near the cell periphery, } \\
\text { as well as in the nascent myofibrils that form as these } \\
\text { structures fuse laterally. }\end{array}$ & [81] \\
\hline FLNB & $\mathrm{R} 24$ & $\begin{array}{l}\text { Heterodimer formation through R24 is possible between } \\
\text { FLNC and B but not between FLNA and the other two } \\
\text { filamins. }\end{array}$ & [33] \\
\hline LL5beta & Co-IP & LL5beta binds $\mathrm{PI}(3,4,5) \mathrm{P} 3$ & [82] \\
\hline PKCalpha & $\mathrm{R} 23-24(\mathrm{Y} 2 \mathrm{H})$ & Phosphorylates filamins & {$[83]$} \\
\hline Migfilin & $\mathrm{R} 21$ & $\begin{array}{l}\text { Migfilin interacts with Mig- } 2 \text { and filamin at cell-matrix } \\
\text { adhesion site and regulate cell shape change. }\end{array}$ & {$[84,85]$} \\
\hline SHIP-2 (INPPL1) & $\begin{array}{l}\mathrm{R} 22-23(\mathrm{Y} 2 \mathrm{H} \text { and } \\
\text { Co-IP) }\end{array}$ & $\begin{array}{c}\text { Filamin-dependent SHIP-2 localization critically regulates } \\
\text { phosphatidylinositol } 3 \text { kinase signaling to the actin } \\
\text { cytoskeleton. }\end{array}$ & [86] \\
\hline $\begin{array}{l}\text { Myozenin-1, 2, } 3 \\
\text { (FATZ, Calsarcins) }\end{array}$ & R19-24 (Y2H) & $\begin{array}{l}\text { Myozenin interacts with FLNC and alpha-actinin in skeletal } \\
\text { muscle Z line. }\end{array}$ & [39-42] \\
\hline KCND2 & $\mathrm{R} 20-24(\mathrm{Y} 2 \mathrm{H})$ & Filamin is required for $\mathrm{Kv} 4.2$ localize at filopodial roots. & [87] \\
\hline Myotilin & $\mathrm{R} 20(\mathrm{Y} 2 \mathrm{H})$ & $\begin{array}{l}\text { Insertion of } 82 \text { amino acid residue in R20 defines specific } \\
\text { localization of FLNC at Z-line and this domain interacts with } \\
\text { myotilin. }\end{array}$ & [7] \\
\hline$\gamma-, \delta$-Sarcoglycans & R20-R24 (Y2H) & The identification of FLNC isoform in muscle. & {$[5,39]$} \\
\hline Actin & $\begin{array}{l}\text { Predicted from } \\
\text { sequence similarity } \\
\text { and localization in } \\
\text { cells. }\end{array}$ & High homology to actin-binding domains of FLNA and B. & [5] \\
\hline
\end{tabular}

\section{Association of FLNC Mutations with Myopathies}

Loss of Flnc gene in mice results in severe defects in myogenesis and myotube structure [52]. In homozygous mice, their skeletal muscles are severely affected, whereas the heart has a normal appearance. However, heterozygous mice are viable and fertile without any abnormalities, demonstrating that neither the low level of wild-type Flnc nor truncated Flnc results in an obvious phenotype [52]. Since human FLNC myofibrillar myopathy slowly progresses, with muscle weakness starting at 24-60 years old, these mutant mice could be analyzed at older age. In humans, a wide variety of myopathy-associated mutations and variants have also demonstrated importance of FLNC in muscle development (Figure 4 and Table 2). 


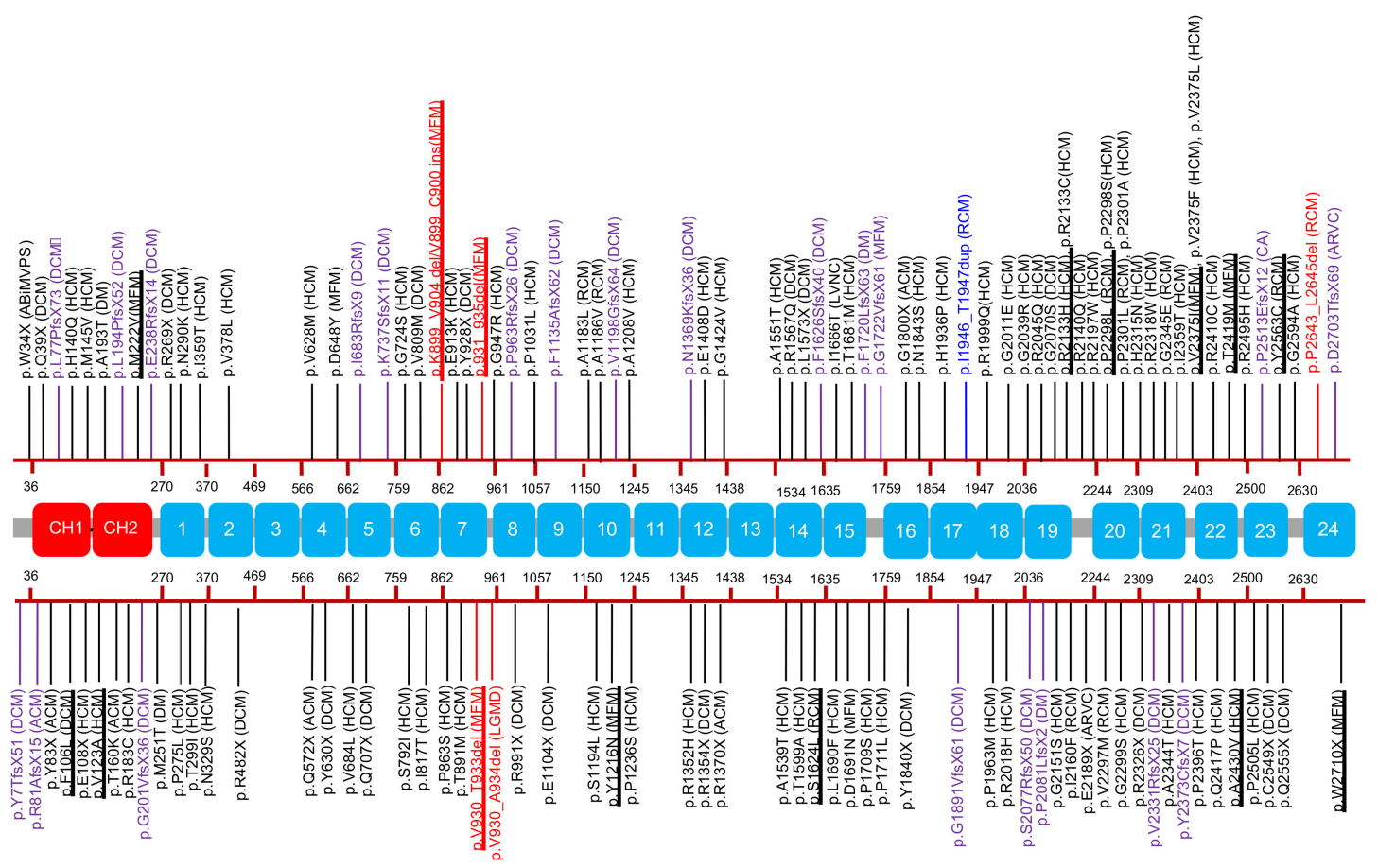

missense/nonsense, deletion, small insertions, frame shift, protein aggregate

Figure 4. A map of how disease-related FLNC mutations are distributed on FLNC domains. Calponin homology $(\mathrm{CH})$ domains are marked with red; Ig-like domains are numbered from 1 to 24 and marked with light blue. Mutations reported in the literatures are mapped to the protein structure. Mutated positions are labeled in color in accordance with the type of mutations: black, missense/nonsense; blue, small insertions; red, deletion; purple, frame shift. Mutation resulted in protein aggregate is underlined. Assignment of FLNC mutations to the corresponding domain structure was based on the UniProt database. Distal myopathy (DM), Myofibrillar myopathy (MFM), Hypertrophic cardiomyopathy (HCM), Restrictive cardiomyopathy (RCM), Dilated cardiomyopathy (DCM), Arrhythmic cardiomyopathy (ACM), Arrhythmogenic right ventricular cardiomyopathy (ARVC), Cardiac arrhythmias (CA), Arrhythmogenic bileaflet mitral valve prolapse syndrome (ABiMVPS), Left ventricular non compaction (LVNC), Limb-girdle muscular dystrophy (LGMD).

Table 2. Mutations of human FLNC gene.

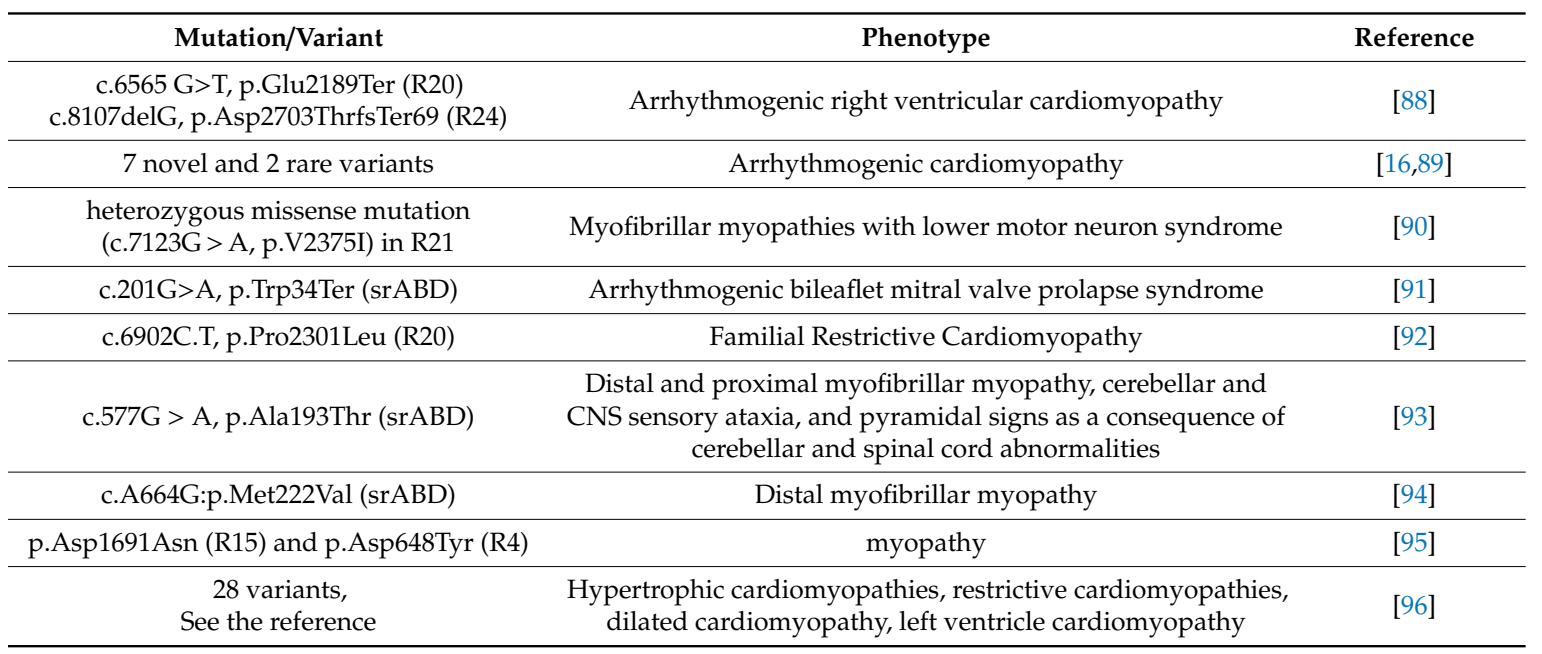


Table 2. Cont.

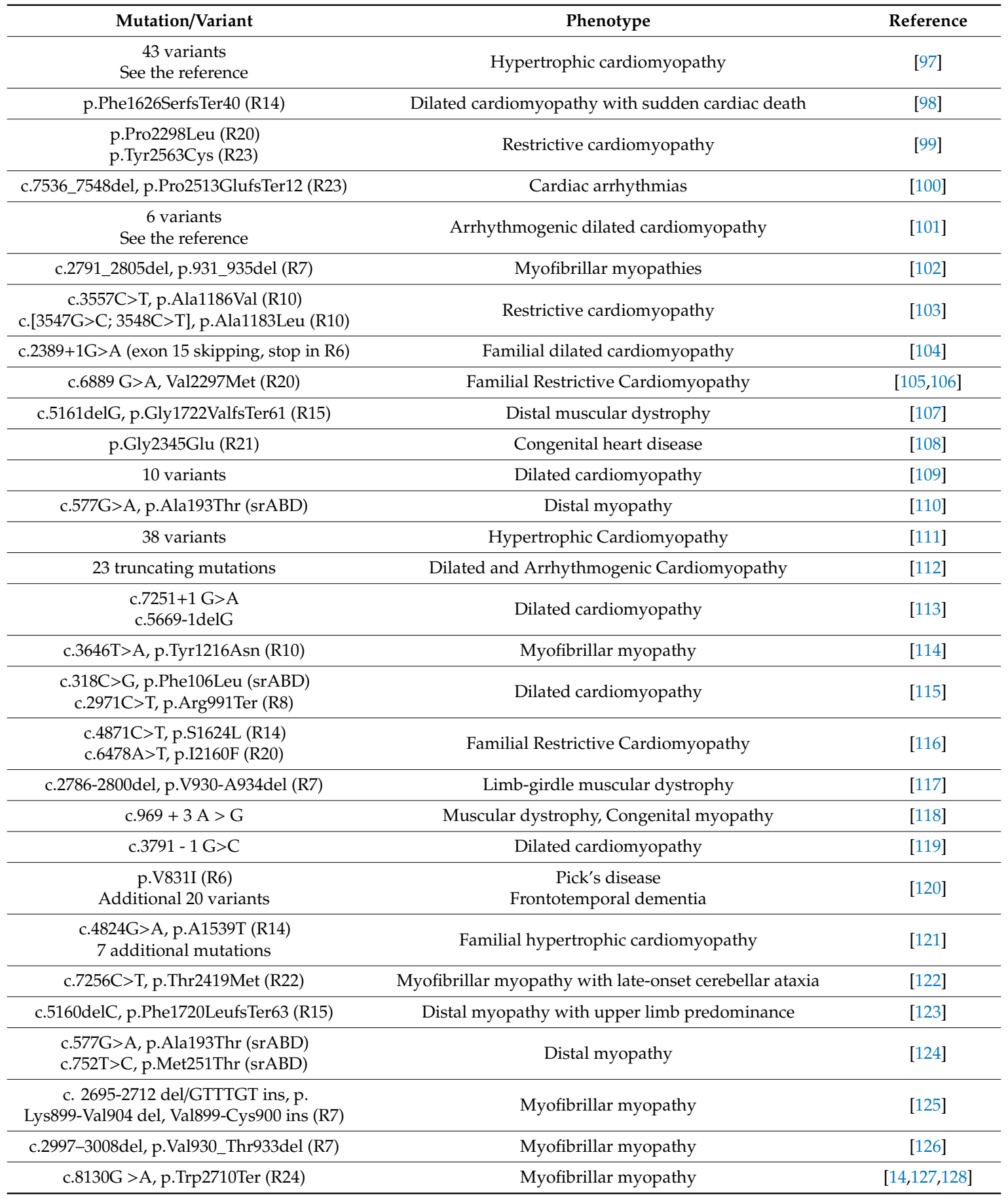

\subsection{FLNC Mutation in Distal and Myofibrillar Skeletal Myopathy}

FLNC mutations have been associated with distal and myofibrillar skeletal myopathies (MFM) [13], characterized by progressive morphological changes of the muscle fibers beginning in the Z-disc and protein aggregates in the sarcoplasm. Mutations in several genes encoding for Z-disc proteins have also been associated with MFM, including myotilin, ZASP, BAG3, desmin, and $\alpha$ B-crystallin [129-133]. The first FLNC-related myopathy was reported in 2005 showing that a nonsense mutation (c.G8130A, p.W2710Ter) in the FLNC dimerization domain causes a disease in a large German family characterized by muscle weakness and typical myofibrillar myopathy features [127]. A few years later, three deletion mutations in FLNC Ig-like domain 7 have been reported: one harboring an internal 
12-nucleotide deletion (c.2997_3008del, p.V930_T933del) [126], the second exhibiting an 18-nucleotide deletion/6 nucleotide insertion (c.2695-2712del/GTTTGT ins, p.K899_V904del/V899_C900ins) [125], and a 15-nucleotide deletion (c.2791_2805del, p.931_935del) [102]. These deletions in the FLNC gene cause protein aggregation, abnormalities in muscle structure, and impairment in muscle fiber function, which leads to muscle weakness.

A frameshift deletion (c.5161delG, p.Gly1722ValfsTer61) (R15) in exon 30 encoding R15 in a Bulgarian family have reported to lead to haploinsufficiency associated with distal muscle weakness primarily in the upper limbs with lower limb involvement upon disease progression [123]. This phenotype differs from those caused by c.577G4A (p.A193T) and c.752T4C (p.M251T) mutations occurring in the actin-binding domain. These mutations have the distinct involvement of hand muscles and induce aggregates of F-actin in cell due to increased affinity of the mutant FLNC to F-actin although the mutant srABD per se are soluble [124]. Interestingly, the p.A193T mutation is also associated with cerebellar and spinal cord abnormalities [93]. Indeed, other studies have shown an association between FLNC and neuronal diseases $[120,123,134]$. However, another mutation in the srABD (c.A664G, p.M222V) showed a predominant leg involvement and myofibrillar aggregates [94]. The mutation in R 21 (c.7123G > A, p.V2375I) is also associated with distal myopathy with aggregation and lower motor neuron syndrome [90]. These data suggest that mutations in srABD and rod domains cause overlapping and distinct clinical symptoms and histopathological changes. Therefore, the relationship between genotype and phenotype remains unclear and may be affected by as-yet unknown genetic and environmental causes [110].

\subsection{FLNC Mutation Development in Cardiomyopathy}

Cardiomyopathy $(\mathrm{CM})$ is a rare disorder of the heart muscle and the leading cause of heart transplantation in children [135]. As listed in Table 2, several reports suggested FLNC as a causal gene for CM and about one-third of the FLNC myofibrillar myopathy patients showed cardiac abnormalities [13]. For example, mutations of p. S1624L in R14 and p.I2160F in R20 cause familial restrictive $\mathrm{CM}(\mathrm{RCM})$, that leads to disorganization of Z-discs. Affected individuals develop heart failure that requires heart transplantation in some cases of children and adults [116]. A splicing mutation in FLNC: c.2389+1G>A could be responsible for cardiac-restricted dilated cardiomyopathy (DCM) [104]. In addition, FLNC variants have been associated with multiple types of CM such as restrictive cardiomyopathy (RCM) and arrhythmic cardiomyopathy (ACM) in the absence of skeletal muscle pathology $[16,88,89,112,113,116,119,121,136]$. Moreover, a recent report has described that FLNC truncating variant may serve as a proarrhythmic genetic substrate for arrhythmogenic bileaflet mitral valve prolapse syndrome [91]. However, sequencing of FLNC gene from 540 hypertrophic cardiomyopathy (HCM) patients and 307 healthy controls, revealed that FLNC mutations are not rare, even in healthy controls, with a frequency of about $4 \%$. This is far higher than HCM prevalence $(0.2 \%)$ in the general population. In addition, FLNC-CM patients rarely have skeletal myopathy, suggesting that the genotype-phenotype relationship of some FLNC mutations might be uncertain and needs to be further evaluated [97].

\subsection{Genotype-Phenotype Correlations in FLNC Mutation}

The genotype-phenotype relationship has great significance for risk management. Among the 117 published FLNC variants, 41 were truncating variants, 70 were missense variants, and 6 were deletion or insertion without shift of the reading frame (Figure 4, Table 2). Regarding the phenotype, 16 variants were associated with a skeletal myopathy phenotype (4 in distal myopathy, 11 in myofibrillar myopathy, and 1 in Limb-girdle muscular dystrophy) and 101 were associated with cardiomyopathy (29 variants in DCM, 50 in HCM, 11 in RCM, 6 in ACM, 2 in arrhythmogenic right ventricular cardiomyopathy (ARVC), 1 in left ventricular noncompaction (LVNC), 1 in Cardiac arrhythmias (CA), and 1 in Arrhythmogenic bileaflet mitral valve prolapse syndrome (ABiMVPS)) (Figure 4). Interestingly, almost all DCM/ACM are caused by loss of function mutations such as 
nonsense, frameshift, or splicing as discussed more details below. In contrast, HCM/RCM mutations are mainly associated with missense variants.

Location of the variants on FLNC molecules causes distinct and overlapping phenotypes and many of the relationships between genotype and phenotype remain unclear. However, mapping the distribution of disease-related variants on FLNC domains reveals some genotype-phenotype relationships (Figure 4). For example, among the 50 published variants in HCM patients, 49 were missense variants. Interestingly, a larger proportion of variants locates in the rod-2 domain, especially between R19 and R22, revealing a cluster of missense variants in the HCM phenotype [97,111,112,121]. These data suggest importance of the rod-2 presumably because the unique insertion of 82 amino acids in R20 interacts with the Z-disc proteins and the rod-2 mediates mechanotransduction (see below).

FLNC variants causing DCM, one of the leading causes of heart failure, have the most direct evidence of a genotype-phenotype relationship. Of the 42 previously reported DCM variants, 16 are frameshifts variants, 2 are missense variants, 13 are splice site variants, while 11 are nonsense variants resulting in an early protein truncation. One of two missense variants found was associated with a null variant in a neonatal case of DCM [115]. In this case, the congenital form of the DCM could be because of the cumulative effect of the missense variant associated with the heteroallelic truncating variant in FLNC. Genetic screening of large DCM patient cohorts revealed an association with truncating FLNC variants (stop codons, frameshifts, and splice site variants), strongly suggesting an overlap between mutation mechanisms and patient phenotype [109,112].

In conclusion, the mutations are distributed in all domains of FLNC protein having mutational hotspots in R24 (p.Trp2710Ter) that is found in patients from diverse ethnic origins $[13,137]$. Biochemical analysis revealed that many of the mutations lead to aggregation of FLNC proteins [99,121,137] (Figure 4). For example, expression of four FLNC mutants (p.V123A, p.A1539T, p.R2133H, and p.A2430V) in cardiac tissue culture cells resulted in the formation of actin aggregates, although FLNC p.A1539T mutant protein itself appears to be soluble [121]. Importantly, the p.Trp2710Ter-induced aggregate blocks autophagy through BAG3 recruitment to the aggregate, suggesting that both BAG3 reduction and autophagy promotion as potential therapies for FLNC p.Trp2710Ter myofibrillar myopathy [14]. Some of the mutations of FLNC might facilitate degradation of the mutant proteins. For example, FLNC c.2997_3008del, R7delVKYT increase susceptibility against protease [138]. In FLNA, V711D, and H743P, mutants are more sensitive to chymotrypsin and disrupt the interaction with protein tyrosine phosphatase PTPN12 [139]. However, effects of the FLNC mutations on partner interaction has never been investigated except for actin [124]. These results indicate that different mutations of FLNC result in diseases of different mechanisms.

\section{Post-Translational Modifications}

PKC $\alpha$ phosphorylates serine residues in mouse FLNC R13, R20, and hinge-2 [140]. Phosphorylation at S2623 and S2624 of human FLNC, which are located in the vicinity of the main calpain 1 cleavage site (Tyr2625), significantly reduces its susceptibility to cleavage [140]. Since the cleavage of hinge-2 removes R24 dimerization domain, mobility of FLNC subunits increases, suggesting that phosphorylation regulates disassembly of the Z-disc [141].

Klhl31, a transcriptional repressor in MAPK/JNK signaling pathway, interacts with FLNC and promote Ub proteasome system-dependent degradation by ubiquitinating FLNC [62]. FLNC can also be ubiquitinated by the cardiac ubiquitin-proteasome system in Fbxl22-dependent fashion [67]. Disruption of Klhl31 in mice resulted in congenital myopathy and knockdown of Fbxl22 leads to progressive reduction of cardiac contractility, suggesting importance of FLNC degradation in normal muscle development.

\section{Mechanotransduction}

Muscles are the major force producing tissue in vertebrates and cardiac tissues are constantly affected by mechanical forces [142]. The muscle Z-disc is not only important for mechanical stability 
and force transmission, but also for mechanotransduction [143]. Although the function of FLNC as a molecule that mediates mechanotransduction is not known, FLNA has been shown to sense mechanical force through actin cytoskeleton by converting the force to biochemical signal $[17,18,144]$. Because FLNC is highly concentrated in the Z-disc and structurally similar to FLNA, it is worth discussing what is known about FLNA as a mechanotransducer. Single molecular analysis revealed that unfolding of FLNA rod-2 can occur by relatively weak forces $(\sim 10 \mathrm{pN})$, which is smaller than rupture forces of FLNA/F-actin interaction $(40-80 \mathrm{pN})$ and actin-actin intermolecular force $(\sim 110 \mathrm{pN})$, whereas unfolding of FLNA rod-1 starts to occur at $50 \mathrm{pN}$ [145-150]. Since a single myosin head can generate 1.7 4 pN force, a couple of myosin molecules are enough to unfold the rod-2 [151,152]. These data indicate that unfolding of Ig domain requires over $50 \mathrm{pN}$ force, whereas dissociation of domain pairs occurs by physiologically relevant force. FLNA R3-R5 in the rod-1 forms domain pairs but dissociation of these domain pairs may require over $50 \mathrm{pN}$ or may be below the measurement limit $[29,147,153]$. The mechanical properties of the FLNC molecule has never been investigated. Because the hinge- 1 is spliced out during myogenesis and FLNC has 82 amino acids insertion in R20, the mechanical property of FLNC could be unique. In addition, how the binding partners interact with FLNC molecules in the Z-disc would influence how forces are transmitted to FLNC molecules. For example, if the binding partner(s) intermolecularly connects FLNC subunits (e.g. rod-1), the rest of the C-terminal domain (e.g. rod-2) may not be unfolded because force may not be transmitted to the C-terminal domain.

Reconstituted FLNA/F-actin/myosin networks revealed that contraction of actomyosin decreases mobility of beta-integrin that binds to the cryptic binding site in FLNA R21 and increases mobility of FilGAP that binds to R23. This demonstrated that the FLNA molecule is a mechano-sensor and -transducer [17] (Figure 5A). Single molecular analysis also showed force-dependent interaction of R21 with the binding partner [144]. The FLNA/beta-integrin interaction is regulated by opening and closing of the CD cleft of R21, where beta-integrin binds (Figure 2B), whereas the FLNA/FilGAP interaction is regulated by changing the distance between the two R23. However, FLNC does not interact with FilGAP, such a mechanism is not involved in FLNC-partner interaction or FLNC interacts with another binding partner in the similar fashion as FilGAP [37]. Based on the structural analysis of FLNC domains as shown in Figure 1 and small-angle X-ray scattering analysis of the FLNC rod-1 [30], we illustrated a model of FLNC structure in Figure 5B. The structure of FLNC R20 has not been solved and whether or not the CD cleft of FLNC R21 is blocked by domain pair is not known. Nevertheless, due to the sequence similarity of FLNC with FLNA, FLNC may mediate mechanotransduction as well.

A

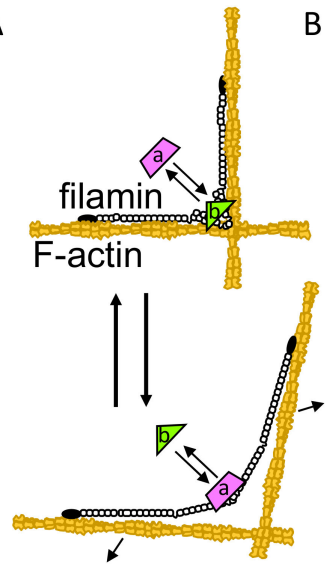

B

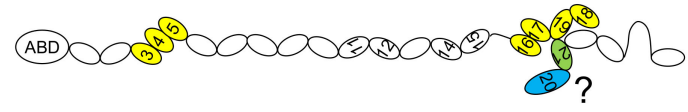

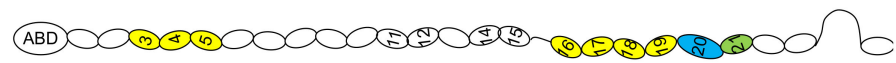

Figure 5. A model of how mechanical forces regulate FLNC-partner interaction. (A) Contractile force of actomyosin or deformation of actin networks induces conformational changes of filamin molecule. Some binding partner (a, e.g., beta-integrin) interacts with exposed binding site under mechanical stress, whereas some (b, e.g., FilGAP for FLNA. FilGAP does not interact with FLNC [37]) dissociates 
when filamin molecule is deformed. (B) Predicted structure of FLNC subunit. Only one subunit is shown. The hinge- 1 is spliced out during myogenesis but strand A of R16 is free from the folded domain, thereby the link between R15 and R16 possesses some flexibility. Colored domain pairs can potentially be dissociated by mechanical force. Because of unique insertion of 82 amino acids in R20 (blue), it is not known if R20 pairs with R21(green) to create cryptic binding site (Figure 2C). Domain pairs of R11-R12 and R14-R15 were suggested by small-angle X-ray scattering analysis but appears to be loose.

\section{Conclusions and Future Perspective}

The ultimate goal of FLNC research should be a cure for FLNC-related myopathy. Although editing the FLNC gene is obviously the best means, preventing the aggregation in the muscle of myopathy patients is another promising strategy. As we unveil the molecular mechanisms of FLNC synthesis and degradation, and the FLNC-mediated signaling pathway, more options should be possible. Revealing how the FLNC molecule is assembled and disassembled in muscle tissue is also beneficial to discovering how to bypass or support mutant FLNC.

Author Contributions: Conceptualization, F.N.; writing-original draft preparation, Z.M. and F.N.; writing-review and editing, Z.M. and F.N.; supervision, F.N.; funding acquisition, F.N. All authors have read and agree to the published version of the manuscript.

Funding: This work is supported by the National Natural Science Foundation of China (31771551 to F.N.).

Conflicts of Interest: The authors declare no conflict of interest.

\section{Abbreviations}

$\begin{array}{ll}\text { FLNC } & \text { Filamin C } \\ \text { F-actin } & \text { Actin filament } \\ \text { ABD } & \text { Actin-binding domain } \\ \text { srABD } & \text { Spectrin-related actin-binding domain } \\ \text { CH } & \text { Calponin homology } \\ \text { MFM } & \text { Myofibrillar myopathy } \\ \text { HCM } & \text { Hypertrophic cardiomyopathy } \\ \text { DM } & \text { Distal myopathy } \\ \text { RCM } & \text { Restrictive cardiomyopathy } \\ \text { DCM } & \text { Dilated cardiomyopathy } \\ \text { ACM } & \text { Arrhythmic cardiomyopathy } \\ \text { ARVC } & \text { Arrhythmogenic right ventricular cardiomyopathy } \\ \text { LGMD } & \text { Limb-girdle muscular dystrophy Cardiac arrhythmias } \\ \text { CA } & \text { Cardiac arrhythmias } \\ \text { ABiMVPS } & \text { Arrhythmogenic bileaflet mitral valve prolapse syndrome } \\ \text { LVNC } & \text { Left ventricular non compaction }\end{array}$

\section{References}

1. Stossel, T.P.; Condeelis, J.; Cooley, L.; Hartwig, J.H.; Noegel, A.; Schleicher, M.; Shapiro, S.S. Filamins as integrators of cell mechanics and signalling. Nat. Rev. Mol. Cell Biol. 2001, 2, 138-145. [CrossRef] [PubMed]

2. Nakamura, F.; Stossel, T.P.; Hartwig, J.H. The filamins: Organizers of cell structure and function. Cell Adhes. Migr. 2011, 5, 160-169. [CrossRef] [PubMed]

3. Maestrini, E.; Patrosso, C.; Mancini, M.; Rivella, S.; Rocchi, M.; Repetto, M.; Villa, A.; Frattini, A.; Zoppe, M.; Vezzoni, P.; et al. Mapping of two genes encoding isoforms of the actin binding protein ABP-280, a dystrophin like protein, to Xq28 and to chromosome 7. Hum. Mol. Genet. 1993, 2, 761-766. [CrossRef] [PubMed]

4. Xie, Z.; Xu, W.; Davie, E.W.; Chung, D.W. Molecular cloning of human ABPL, an actin-binding protein homologue. Biochem. Biophys. Res. Commun. 1998, 251, 914-919. [CrossRef] 
5. Thompson, T.G.; Chan, Y.M.; Hack, A.A.; Brosius, M.; Rajala, M.; Lidov, H.G.; McNally, E.M.; Watkins, S.; Kunkel, L.M. Filamin 2 (FLN2): A muscle-specific sarcoglycan interacting protein. J. Cell Biol. 2000, 148, 115-126. [CrossRef]

6. Van der Ven, P.F.; Obermann, W.M.; Lemke, B.; Gautel, M.; Weber, K.; Furst, D.O. Characterization of muscle filamin isoforms suggests a possible role of gamma-filamin/ABP-L in sarcomeric Z-disc formation. Cell Motil. Cytoskelet. 2000, 45, 149-162. [CrossRef]

7. Van der Ven, P.F.; Wiesner, S.; Salmikangas, P.; Auerbach, D.; Himmel, M.; Kempa, S.; Hayess, K.; Pacholsky, D.; Taivainen, A.; Schroder, R.; et al. Indications for a novel muscular dystrophy pathway. gamma-filamin, the muscle-specific filamin isoform, interacts with myotilin. J. Cell Biol. 2000, 151, 235-248. [CrossRef]

8. Baldassarre, M.; Razinia, Z.; Burande, C.F.; Lamsoul, I.; Lutz, P.G.; Calderwood, D.A. Filamins regulate cell spreading and initiation of cell migration. PLoS ONE 2009, 4, e7830. [CrossRef]

9. Kesner, B.A.; Milgram, S.L.; Temple, B.R.; Dokholyan, N.V. Isoform divergence of the filamin family of proteins. Mol. Biol. Evol. 2010, 27, 283-295. [CrossRef]

10. Feng, Y.; Chen, M.H.; Moskowitz, I.P.; Mendonza, A.M.; Vidali, L.; Nakamura, F.; Kwiatkowski, D.J.; Walsh, C.A. Filamin A (FLNA) is required for cell-cell contact in vascular development and cardiac morphogenesis. Proc. Natl. Acad. Sci. USA 2006, 103, 19836-19841. [CrossRef]

11. Zhou, X.; Tian, F.; Sandzen, J.; Cao, R.; Flaberg, E.; Szekely, L.; Cao, Y.; Ohlsson, C.; Bergo, M.O.; Boren, J.; et al. Filamin B deficiency in mice results in skeletal malformations and impaired microvascular development. Proc. Natl. Acad. Sci. USA 2007, 104, 3919-3924. [CrossRef]

12. Kyndt, F.; Gueffet, J.P.; Probst, V.; Jaafar, P.; Legendre, A.; Le Bouffant, F.; Toquet, C.; Roy, E.; McGregor, L.; Lynch, S.A.; et al. Mutations in the gene encoding filamin A as a cause for familial cardiac valvular dystrophy. Circulation 2007, 115, 40-49. [CrossRef]

13. Furst, D.O.; Goldfarb, L.G.; Kley, R.A.; Vorgerd, M.; Olive, M.; van der Ven, P.F. Filamin C-related myopathies: Pathology and mechanisms. Acta Neuropathol. 2013, 125, 33-46. [CrossRef] [PubMed]

14. Ruparelia, A.A.; Oorschot, V.; Ramm, G.; Bryson-Richardson, R.J. FLNC myofibrillar myopathy results from impaired autophagy and protein insufficiency. Hum. Mol. Genet. 2016, 25, 2131-2142. [CrossRef] [PubMed]

15. Brodehl, A.; Gaertner-Rommel, A.; Milting, H. FLNC (Filamin-C): A New(er) Player in the Field of Genetic Cardiomyopathies. Circ. Cardiovasc. Genet. 2017, 10. [CrossRef] [PubMed]

16. Hall, C.L.; Akhtar, M.M.; Sabater-Molina, M.; Futema, M.; Asimaki, A.; Protonotarios, A.; Dalageorgou, C.; Pittman, A.M.; Suarez, M.P.; Aguilera, B.; et al. Filamin C variants are associated with a distinctive clinical and immunohistochemical arrhythmogenic cardiomyopathy phenotype. Int. J. Cardiol. 2019, in press. [CrossRef]

17. Ehrlicher, A.J.; Nakamura, F.; Hartwig, J.H.; Weitz, D.A.; Stossel, T.P. Mechanical strain in actin networks regulates FilGAP and integrin binding to filamin A. Nature 2011, 478, 260-263. [CrossRef]

18. Razinia, Z.; Makela, T.; Ylanne, J.; Calderwood, D.A. Filamins in mechanosensing and signaling. Annu. Rev. Biophys. 2012, 41, 227-246. [CrossRef]

19. Modarres, H.P.; Mofradt, M.R. Filamin: A structural and functional biomolecule with important roles in cell biology, signaling and mechanics. Mol. Cell. Biomech. 2014, 11, 39-65.

20. Gariboldi, M.; Maestrini, E.; Canzian, F.; Manenti, G.; De Gregorio, L.; Rivella, S.; Chatterjee, A.; Herman, G.E.; Archidiacono, N.; Antonacci, R.; et al. Comparative mapping of the actin-binding protein 280 genes in human and mouse. Genomics 1994, 21, 428-430. [CrossRef]

21. Chakarova, C.; Wehnert, M.S.; Uhl, K.; Sakthivel, S.; Vosberg, H.P.; van der Ven, P.F.; Furst, D.O. Genomic structure and fine mapping of the two human filamin gene paralogues FLNB and FLNC and comparative analysis of the filamin gene family. Hum. Genet. 2000, 107, 597-611. [CrossRef] [PubMed]

22. Van der Flier, A.; Kuikman, I.; Kramer, D.; Geerts, D.; Kreft, M.; Takafuta, T.; Shapiro, S.S.; Sonnenberg, A. Different splice variants of filamin-B affect myogenesis, subcellular distribution, and determine binding to integrin [beta] subunits. J. Cell Biol. 2002, 156, 361-376. [CrossRef] [PubMed]

23. Korenbaum, E.; Rivero, F. Calponin homology domains at a glance. J Cell Sci 2002, 115, 3543-3545. [CrossRef] [PubMed]

24. Nakamura, F.; Hartwig, J.H.; Stossel, T.P.; Szymanski, P.T. Ca2+ and calmodulin regulate the binding of filamin A to actin filaments. J. Biol. Chem. 2005, 280, 32426-32433. [CrossRef] 
25. Gorlin, J.B.; Yamin, R.; Egan, S.; Stewart, M.; Stossel, T.P.; Kwiatkowski, D.J.; Hartwig, J.H. Human endothelial actin-binding protein (ABP-280, nonmuscle filamin): A molecular leaf spring. J. Cell Biol. 1990, 111, 1089-1105. [CrossRef]

26. Lad, Y.; Kiema, T.; Jiang, P.; Pentikainen, O.T.; Coles, C.H.; Campbell, I.D.; Calderwood, D.A.; Ylanne, J. Structure of three tandem filamin domains reveals auto-inhibition of ligand binding. EMBO J. 2007, 26, 3993-4004. [CrossRef]

27. Nakamura, F.; Osborn, T.M.; Hartemink, C.A.; Hartwig, J.H.; Stossel, T.P. Structural basis of filamin A functions. J. Cell Biol. 2007, 179, 1011-1025. [CrossRef]

28. Tossavainen, H.; Koskela, O.; Jiang, P.; Ylanne, J.; Campbell, I.D.; Kilpelainen, I.; Permi, P. Model of a six immunoglobulin-like domain fragment of filamin A (16-21) built using residual dipolar couplings. J. Am. Chem. Soc. 2012, 134, 6660-6672. [CrossRef]

29. Sethi, R.; Seppala, J.; Tossavainen, H.; Ylilauri, M.; Ruskamo, S.; Pentikainen, O.T.; Pentikainen, U.; Permi, P.; Ylanne, J. A novel structural unit in the N-terminal region of filamins. J. Biol. Chem. 2014, 289, 8588-8598. [CrossRef]

30. Sethi, R.; Ylanne, J. Small-angle X-ray scattering reveals compact domain-domain interactions in the N-terminal region of filamin C. PLoS ONE 2014, 9, e107457. [CrossRef]

31. Suphamungmee, W.; Nakamura, F.; Hartwig, J.H.; Lehman, W. Electron microscopy and 3D reconstruction reveals filamin Ig domain binding to F-actin. J. Mol. Biol. 2012, 424, 248-256. [CrossRef] [PubMed]

32. Sheen, V.L.; Feng, Y.; Graham, D.; Takafuta, T.; Shapiro, S.S.; Walsh, C.A. Filamin A and Filamin B are co-expressed within neurons during periods of neuronal migration and can physically interact. Hum. Mol. Genet. 2002, 11, 2845-2854. [CrossRef] [PubMed]

33. Himmel, M.; Van Der Ven, P.F.; Stocklein, W.; Furst, D.O. The limits of promiscuity: Isoform-specific dimerization of filamins. Biochemistry 2003, 42, 430-439. [CrossRef] [PubMed]

34. Nakamura, F.; Pudas, R.; Heikkinen, O.; Permi, P.; Kilpelainen, I.; Munday, A.D.; Hartwig, J.H.; Stossel, T.P.; Ylanne, J. The structure of the GPIb-filamin A complex. Blood 2006, 107, 1925-1932. [CrossRef]

35. Wang, J.; Nakamura, F. Identification of Filamin A Mechanobinding Partner II: Fimbacin Is a Novel Actin Cross-Linking and Filamin A Binding Protein. Biochemistry 2019, 58, 4737-4743. [CrossRef]

36. Wang, L.; Nakamura, F. Identification of Filamin A Mechanobinding Partner I: Smoothelin Specifically Interacts with the Filamin A Mechanosensitive Domain 21. Biochemistry 2019, 58, 4726-4736. [CrossRef]

37. Nakamura, F.; Heikkinen, O.; Pentikainen, O.T.; Osborn, T.M.; Kasza, K.E.; Weitz, D.A.; Kupiainen, O.; Permi, P.; Kilpelainen, I.; Ylanne, J.; et al. Molecular basis of filamin A-FilGAP interaction and its impairment in congenital disorders associated with filamin A mutations. PLoS ONE 2009, 4, e4928. [CrossRef]

38. Selcen, D. Myofibrillar myopathies. Neuromuscul. Disord. 2011, 21, 161-171. [CrossRef]

39. Gontier, Y.; Taivainen, A.; Fontao, L.; Sonnenberg, A.; van der Flier, A.; Carpen, O.; Faulkner, G.; Borradori, L. The Z-disc proteins myotilin and FATZ-1 interact with each other and are connected to the sarcolemma via muscle-specific filamins. J. Cell Sci. 2005, 118, 3739-3749. [CrossRef]

40. Faulkner, G.; Pallavicini, A.; Comelli, A.; Salamon, M.; Bortoletto, G.; Ievolella, C.; Trevisan, S.; Kojic, S.; Dalla Vecchia, F.; Laveder, P.; et al. FATZ, a filamin-, actinin-, and telethonin-binding protein of the Z-disc of skeletal muscle. J. Biol. Chem. 2000, 275, 41234-41242. [CrossRef]

41. Takada, F.; Vander Woude, D.L.; Tong, H.Q.; Thompson, T.G.; Watkins, S.C.; Kunkel, L.M.; Beggs, A.H. Myozenin: An alpha-actinin- and gamma-filamin-binding protein of skeletal muscle $\mathrm{Z}$ lines. Proc. Natl. Acad. Sci. USA 2001, 98, 1595-1600. [CrossRef] [PubMed]

42. Frey, N.; Olson, E.N. Calsarcin-3, a novel skeletal muscle-specific member of the calsarcin family, interacts with multiple Z-disc proteins. J. Biol. Chem. 2002, 277, 13998-14004. [CrossRef] [PubMed]

43. Linnemann, A.; van der Ven, P.F.; Vakeel, P.; Albinus, B.; Simonis, D.; Bendas, G.; Schenk, J.A.; Micheel, B.; Kley, R.A.; Furst, D.O. The sarcomeric Z-disc component myopodin is a multiadapter protein that interacts with filamin and alpha-actinin. Eur. J. Cell Biol. 2010, 89, 681-692. [CrossRef] [PubMed]

44. Zhang, M.; Liu, J.; Cheng, A.; Deyoung, S.M.; Saltiel, A.R. Identification of CAP as a costameric protein that interacts with filamin C. Mol. Biol. Cell 2007, 18, 4731-4740. [CrossRef]

45. Van der Ven, P.F.; Ehler, E.; Vakeel, P.; Eulitz, S.; Schenk, J.A.; Milting, H.; Micheel, B.; Furst, D.O. Unusual splicing events result in distinct $X$ in isoforms that associate differentially with filamin c and Mena/VASP. Exp. Cell. Res. 2006, 312, 2154-2167. [CrossRef] 
46. Kley, R.A.; Maerkens, A.; Leber, Y.; Theis, V.; Schreiner, A.; van der Ven, P.F.; Uszkoreit, J.; Stephan, C.; Eulitz, S.; Euler, N.; et al. A combined laser microdissection and mass spectrometry approach reveals new disease relevant proteins accumulating in aggregates of filaminopathy patients. Mol. Cell. Proteom. 2013, 12, 215-227. [CrossRef]

47. Eulitz, S.; Sauer, F.; Pelissier, M.C.; Boisguerin, P.; Molt, S.; Schuld, J.; Orfanos, Z.; Kley, R.A.; Volkmer, R.; Wilmanns, M.; et al. Identification of Xin-repeat proteins as novel ligands of the SH3 domains of nebulin and nebulette and analysis of their interaction during myofibril formation and remodeling. Mol. Biol. Cell 2013, 24, 3215-3226. [CrossRef]

48. Chevessier, F.; Schuld, J.; Orfanos, Z.; Plank, A.C.; Wolf, L.; Maerkens, A.; Unger, A.; Schlotzer-Schrehardt, U.; Kley, R.A.; Von Horsten, S.; et al. Myofibrillar instability exacerbated by acute exercise in filaminopathy. Hum. Mol. Genet. 2015, 24, 7207-7220. [CrossRef]

49. Yu, J.G.; Furst, D.O.; Thornell, L.E. The mode of myofibril remodelling in human skeletal muscle affected by DOMS induced by eccentric contractions. Histochem. Cell Biol. 2003, 119, 383-393. [CrossRef]

50. Yu, J.G.; Carlsson, L.; Thornell, L.E. Evidence for myofibril remodeling as opposed to myofibril damage in human muscles with DOMS: An ultrastructural and immunoelectron microscopic study. Histochem. Cell Biol. 2004, 121, 219-227. [CrossRef]

51. Orfanos, Z.; Godderz, M.P.; Soroka, E.; Godderz, T.; Rumyantseva, A.; van der Ven, P.F.; Hawke, T.J.; Furst, D.O. Breaking sarcomeres by in vitro exercise. Sci. Rep. 2016, 6, 19614. [CrossRef]

52. Dalkilic, I.; Schienda, J.; Thompson, T.G.; Kunkel, L.M. Loss of FilaminC (FLNc) results in severe defects in myogenesis and myotube structure. Mol. Cell. Biol. 2006, 26, 6522-6534. [CrossRef] [PubMed]

53. Spiro, D. The ultrastructure of striated muscle at various sarcomere lengths. J. Biophys. Biochem. Cytol. 1956, 2 (Suppl. 4), 157-162. [CrossRef] [PubMed]

54. Knappeis, G.G.; Carlsen, F. The ultrastructure of the Z disc in skeletal muscle. J. Cell Biol. 1962, 13, 323-335. [CrossRef] [PubMed]

55. Horowits, R. The physiological role of titin in striated muscle. Rev. Physiol. Biochem. Pharmacol. 1999, 138, 57-96. [PubMed]

56. Huddart, H. The Comparative Structure and Function of Muscle; Pergamon Press: New York, NY, USA, 1975.

57. Luther, P.K. The vertebrate muscle Z-disc: Sarcomere anchor for structure and signalling. J. Muscle Res. Cell Motil. 2009, 30, 171-185. [CrossRef]

58. Anastasi, G.; Cutroneo, G.; Trimarchi, F.; Santoro, G.; Bruschetta, D.; Bramanti, P.; Pisani, A.; Favaloro, A. Evaluation of sarcoglycans, vinculin-talin-integrin system and filamin2 in alpha- and gamma-sarcoglycanopathy: An immunohistochemical study. Int. J. Mol. Med. 2004, 14, 989-999.

59. Leber, Y.; Ruparelia, A.A.; Kirfel, G.; van der Ven, P.F.; Hoffmann, B.; Merkel, R.; Bryson-Richardson, R.J.; Furst, D.O. Filamin C is a highly dynamic protein associated with fast repair of myofibrillar microdamage. Hum. Mol. Genet. 2016, 25, 2776-2788. [CrossRef]

60. Collier, M.P.; Alderson, T.R.; de Villiers, C.P.; Nicholls, D.; Gastall, H.Y.; Allison, T.M.; Degiacomi, M.T.; Jiang, H.; Mlynek, G.; Furst, D.O.; et al. HspB1 phosphorylation regulates its intramolecular dynamics and mechanosensitive molecular chaperone interaction with filamin C. Sci. Adv. 2019, 5, eaav8421. [CrossRef]

61. Yang, B.; Liu, Y.; Zhao, J.; Hei, K.; Zhuang, H.; Li, Q.; Wei, W.; Chen, R.; Zhang, N.; Li, Y. Ectopic overexpression of filamin C scaffolds MEK1/2 and ERK1/2 to promote the progression of human hepatocellular carcinoma. Cancer Lett. 2017, 388, 167-176. [CrossRef]

62. Papizan, J.B.; Garry, G.A.; Brezprozvannaya, S.; McAnally, J.R.; Bassel-Duby, R.; Liu, N.; Olson, E.N. Deficiency in Kelch protein Klhl31 causes congenital myopathy in mice. J. Clin. Investig. 2017, 127, 3730-3740. [CrossRef] [PubMed]

63. Juo, L.Y.; Liao, W.C.; Shih, Y.L.; Yang, B.Y.; Liu, A.B.; Yan, Y.T. HSPB7 interacts with dimerized FLNC and its absence results in progressive myopathy in skeletal muscles. J. Cell Sci. 2016, 129, 1661-1670. [CrossRef] [PubMed]

64. Neethling, A.; Mouton, J.; Loos, B.; Corfield, V.; de Villiers, C.; Kinnear, C. Filamin C: A novel component of the KCNE2 interactome during hypoxia. Cardiovasc. J. Afr. 2016, 27, 4-11. [CrossRef]

65. Pawlowski, M.; Saraswathi, S.; Motawea, H.K.; Chotani, M.A.; Kloczkowski, A. In silico modeling of human alpha2C-adrenoreceptor interaction with filamin-2. PLoS ONE 2014, 9, e103099. [CrossRef] 
66. Molt, S.; Buhrdel, J.B.; Yakovlev, S.; Schein, P.; Orfanos, Z.; Kirfel, G.; Winter, L.; Wiche, G.; van der Ven, P.F.; Rottbauer, W.; et al. Aciculin interacts with filamin $C$ and Xin and is essential for myofibril assembly, remodeling and maintenance. J. Cell Sci. 2014, 127, 3578-3592. [CrossRef] [PubMed]

67. Spaich, S.; Will, R.D.; Just, S.; Spaich, S.; Kuhn, C.; Frank, D.; Berger, I.M.; Wiemann, S.; Korn, B.; Koegl, M.; et al. F-box and leucine-rich repeat protein 22 is a cardiac-enriched F-box protein that regulates sarcomeric protein turnover and is essential for maintenance of contractile function in vivo. Circ. Res. 2012, 111, 1504-1516. [CrossRef]

68. Maiweilidan, Y.; Klauza, I.; Kordeli, E. Novel interactions of ankyrins-G at the costameres: The muscle-specific Obscurin/Titin-Binding-related Domain (OTBD) binds plectin and filamin C. Exp. Cell Res. 2011, 317, 724-736. [CrossRef]

69. Baker, J.; Riley, G.; Romero, M.R.; Haynes, A.R.; Hilton, H.; Simon, M.; Hancock, J.; Tateossian, H.; Ripoll, V.M.; Blanco, G. Identification of a Z-band associated protein complex involving KY, FLNC and IGFN1. Exp. Cell Res. 2010, 316, 1856-1870. [CrossRef]

70. Nakagawa, K.; Sugahara, M.; Yamasaki, T.; Kajiho, H.; Takahashi, S.; Hirayama, J.; Minami, Y.; Ohta, Y.; Watanabe, T.; Hata, Y.; et al. Filamin associates with stress signalling kinases MKK7 and MKK4 and regulates JNK activation. Biochem. J. 2010, 427, 237-245. [CrossRef]

71. Arndt, V.; Dick, N.; Tawo, R.; Dreiseidler, M.; Wenzel, D.; Hesse, M.; Furst, D.O.; Saftig, P.; Saint, R.; Fleischmann, B.K.; et al. Chaperone-assisted selective autophagy is essential for muscle maintenance. Curr. Biol. 2010, 20, 143-148. [CrossRef]

72. Bosch-Comas, A.; Lindsten, K.; Gonzalez-Duarte, R.; Masucci, M.G.; Marfany, G. The ubiquitin-specific protease USP25 interacts with three sarcomeric proteins. Cell. Mol. Life Sci. 2006, 63, 723-734. [CrossRef] [PubMed]

73. Labeit, S.; Lahmers, S.; Burkart, C.; Fong, C.; McNabb, M.; Witt, S.; Witt, C.; Labeit, D.; Granzier, H. Expression of distinct classes of titin isoforms in striated and smooth muscles by alternative splicing, and their conserved interaction with filamins. J. Mol. Biol. 2006, 362, 664-681. [CrossRef] [PubMed]

74. Raynaud, F.; Jond-Necand, C.; Marcilhac, A.; Furst, D.; Benyamin, Y. Calpain 1-gamma filamin interaction in muscle cells: A possible in situ regulation by PKC-alpha. Int. J. Biochem. Cell Biol. 2006, 38, 404-413. [CrossRef] [PubMed]

75. Kim, K.M.; Gainetdinov, R.R.; Laporte, S.A.; Caron, M.G.; Barak, L.S. G protein-coupled receptor kinase regulates dopamine D3 receptor signaling by modulating the stability of a receptor-filamin-beta-arrestin complex. A case of autoreceptor regulation. J. Biol. Chem. 2005, 280, 12774-12780. [CrossRef]

76. Lypowy, J.; Chen, I.Y.; Abdellatif, M. An alliance between Ras GTPase-activating protein, filamin C, and Ras GTPase-activating protein SH3 domain-binding protein regulates myocyte growth. J. Biol. Chem. 2005, 280, 25717-25728. [CrossRef] [PubMed]

77. Murray, J.T.; Campbell, D.G.; Peggie, M.; Mora, A.; Cohen, P. Identification of filamin C as a new physiological substrate of PKBalpha using KESTREL. Biochem. J. 2004, 384, 489-494. [CrossRef] [PubMed]

78. Beatham, J.; Romero, R.; Townsend, S.K.; Hacker, T.; van der Ven, P.F.; Blanco, G. Filamin C interacts with the muscular dystrophy $\mathrm{KY}$ protein and is abnormally distributed in mouse KY deficient muscle fibres. Hum. Mol. Genet. 2004, 13, 2863-2874. [CrossRef]

79. Zhang, T.; Xu, Q.; Chen, F.R.; Han, Q.D.; Zhang, Y.Y. Yeast two-hybrid screening for proteins that interact with alpha1-adrenergic receptors. Acta Pharmacol. Sin. 2004, 25, 1471-1478.

80. Guyon, J.R.; Kudryashova, E.; Potts, A.; Dalkilic, I.; Brosius, M.A.; Thompson, T.G.; Beckmann, J.S.; Kunkel, L.M.; Spencer, M.J. Calpain 3 cleaves filamin C and regulates its ability to interact with gamma- and delta-sarcoglycans. Muscle Nerve 2003, 28, 472-483. [CrossRef]

81. Lu, S.; Carroll, S.L.; Herrera, A.H.; Ozanne, B.; Horowits, R. New N-RAP-binding partners alpha-actinin, filamin and Krp1 detected by yeast two-hybrid screening: Implications for myofibril assembly. J. Cell Sci. 2003, 116, 2169-2178. [CrossRef]

82. Paranavitane, V.; Coadwell, W.J.; Eguinoa, A.; Hawkins, P.T.; Stephens, L. LL5beta is a phosphatidylinositol $(3,4,5)$-trisphosphate sensor that can bind the cytoskeletal adaptor, gamma-filamin. J. Biol. Chem. 2003, 278, 1328-1335. [CrossRef]

83. Tigges, U.; Koch, B.; Wissing, J.; Jockusch, B.M.; Ziegler, W.H. The F-actin cross-linking and focal adhesion protein filamin A is a ligand and in vivo substrate for protein kinase C alpha. J. Biol. Chem. 2003, 278, 23561-23569. [CrossRef] 
84. Tu, Y.; Wu, S.; Shi, X.; Chen, K.; Wu, C. Migfilin and Mig-2 link focal adhesions to filamin and the actin cytoskeleton and function in cell shape modulation. Cell 2003, 113, 37-47. [CrossRef]

85. Ithychanda, S.S.; Das, M.; Ma, Y.Q.; Ding, K.; Wang, X.; Gupta, S.; Wu, C.; Plow, E.F.; Qin, J. Migfilin, a molecular switch in regulation of integrin activation. J. Biol. Chem. 2009, 284, 4713-4722. [CrossRef]

86. Dyson, J.M.; O'Malley, C.J.; Becanovic, J.; Munday, A.D.; Berndt, M.C.; Coghill, I.D.; Nandurkar, H.H.; Ooms, L.M.; Mitchell, C.A. The SH2-containing inositol polyphosphate 5-phosphatase, SHIP-2, binds filamin and regulates submembraneous actin. J. Cell Biol. 2001, 155, 1065-1079. [CrossRef]

87. Petrecca, K.; Miller, D.M.; Shrier, A. Localization and enhanced current density of the Kv4.2 potassium channel by interaction with the actin-binding protein filamin. J. Neurosci. 2000, 20, 8736-8744. [CrossRef]

88. Brun, F.; Gigli, M.; Graw, S.L.; Judge, D.P.; Merlo, M.; Murray, B.; Calkins, H.; Sinagra, G.; Taylor, M.R.; Mestroni, L.; et al. FLNC truncations cause arrhythmogenic right ventricular cardiomyopathy. J. Med. Genet. 2020, 57, 254-257. [CrossRef]

89. Hall, C.L.; Gurha, P.; Sabater-Molina, M.; Asimaki, A.; Futema, M.; Lovering, R.C.; Suarez, M.P.; Aguilera, B.; Molina, P.; Zorio, E.; et al. RNA sequencing-based transcriptome profiling of cardiac tissue implicates novel putative disease mechanisms in FLNC-associated arrhythmogenic cardiomyopathy. Int. J. Cardiol. 2020, 302, 124-130. [CrossRef]

90. Chen, J.; Wu, J.; Han, C.; Li, Y.; Guo, Y.; Tong, X. A mutation in the filamin c gene causes myofibrillar myopathy with lower motor neuron syndrome: A case report. BMC Neurol. 2019, 19, 198. [CrossRef]

91. Bains, S.; Tester, D.J.; Asirvatham, S.J.; Noseworthy, P.A.; Ackerman, M.J.; Giudicessi, J.R. A Novel Truncating Variant in FLNC-Encoded Filamin C May Serve as a Proarrhythmic Genetic Substrate for Arrhythmogenic Bileaflet Mitral Valve Prolapse Syndrome. Mayo Clin. Proc. 2019, 94, 906-913. [CrossRef]

92. Roldan-Sevilla, A.; Palomino-Doza, J.; de Juan, J.; Sanchez, V.; Dominguez-Gonzalez, C.; Salguero-Bodes, R.; Arribas-Ynsaurriaga, F. Missense Mutations in the FLNC Gene Causing Familial Restrictive Cardiomyopathy. Circ. Genom. Precis. Med. 2019, 12, e002388. [CrossRef]

93. Previtali, S.C.; Scarlato, M.; Vezzulli, P.; Ruggieri, A.; Velardo, D.; Benedetti, S.; Torini, G.; Colombo, B.; Maggi, L.; Di Bella, D.; et al. Expanding the central nervous system disease spectrum associated with FLNC mutation. Muscle Nerve 2019, 59, E33-E37. [CrossRef]

94. Gemelli, C.; Prada, V.; Fiorillo, C.; Fabbri, S.; Maggi, L.; Geroldi, A.; Gibertini, S.; Mandich, P.; Trevisan, L.; Fossa, P.; et al. A novel mutation in the N-terminal acting-binding domain of Filamin $\mathrm{C}$ protein causing a distal myofibrillar myopathy. J. Neurol. Sci. 2019, 398, 75-78. [CrossRef]

95. Zhang, Y.T.; Pu, C.Q.; Ban, R.; Liu, H.X.; Shi, Q.; Lu, X.H. Clinical, Pathological, and Genetic Features of Two Chinese Cases with Filamin C Myopathy. Chin. Med. J. (Engl.) 2018, 131, 2986-2988. [CrossRef]

96. Ader, F.; De Groote, P.; Reant, P.; Rooryck-Thambo, C.; Dupin-Deguine, D.; Rambaud, C.; Khraiche, D.; Perret, C.; Pruny, J.F.; Mathieu-Dramard, M.; et al. FLNC pathogenic variants in patients with cardiomyopathies: Prevalence and genotype-phenotype correlations. Clin. Genet. 2019, 96, 317-329. [CrossRef]

97. Cui, H.; Wang, J.; Zhang, C.; Wu, G.; Zhu, C.; Tang, B.; Zou, Y.; Huang, X.; Hui, R.; Song, L.; et al. Mutation profile of FLNC gene and its prognostic relevance in patients with hypertrophic cardiomyopathy. Mol. Genet. Genom. Med. 2018, 6, 1104-1113. [CrossRef]

98. Sveinbjornsson, G.; Olafsdottir, E.F.; Thorolfsdottir, R.B.; Davidsson, O.B.; Helgadottir, A.; Jonasdottir, A.; Jonasdottir, A.; Bjornsson, E.; Jensson, B.O.; Arnadottir, G.A.; et al. Variants in NKX2-5 and FLNC Cause Dilated Cardiomyopathy and Sudden Cardiac Death. Circ. Genom. Precis. Med. 2018, 11, e002151. [CrossRef]

99. Schubert, J.; Tariq, M.; Geddes, G.; Kindel, S.; Miller, E.M.; Ware, S.M. Novel pathogenic variants in filamin C identified in pediatric restrictive cardiomyopathy. Hum. Mutat. 2018, 39, 2083-2096. [CrossRef]

100. Mangum, K.D.; Ferns, S.J. A novel familial truncating mutation in the filamin $C$ gene associated with cardiac arrhythmias. Eur. J. Med. Genet. 2019, 62, 282-285. [CrossRef]

101. Begay, R.L.; Graw, S.L.; Sinagra, G.; Asimaki, A.; Rowland, T.J.; Slavov, D.B.; Gowan, K.; Jones, K.L.; Brun, F.; Merlo, M.; et al. Filamin C Truncation Mutations Are Associated with Arrhythmogenic Dilated Cardiomyopathy and Changes in the Cell-Cell Adhesion Structures. JACC Clin. Electrophysiol. 2018, 4, 504-514. [CrossRef]

102. Miao, J.; Su, F.F.; Liu, X.M.; Wei, X.J.; Yuan, Y.; Yu, X.F. A case report: A heterozygous deletion (2791_2805 del) in exon 18 of the filamin $C$ gene causing filamin C-related myofibrillar myopathies in a Chinese family. BMC Neurol. 2018, 18, 79. [CrossRef] 
103. Kiselev, A.; Vaz, R.; Knyazeva, A.; Khudiakov, A.; Tarnovskaya, S.; Liu, J.; Sergushichev, A.; Kazakov, S.; Frishman, D.; Smolina, N.; et al. De novo mutations in FLNC leading to early-onset restrictive cardiomyopathy and congenital myopathy. Hum. Mutat. 2018, 39, 1161-1172. [CrossRef]

104. Nozari, A.; Aghaei-Moghadam, E.; Zeinaloo, A.; Mollazadeh, R.; Majnoon, M.T.; Alavi, A.; Ghasemi Firouzabadi, S.; Mohammadzadeh, A.; Banihashemi, S.; Nikzaban, M.; et al. A novel splicing variant in FLNC gene responsible for a highly penetrant familial dilated cardiomyopathy in an extended Iranian family. Gene 2018, 659, 160-167. [CrossRef]

105. Ma, Y.; Huang, J.; Zhou, Z. Letter by Ma et al Regarding Article, "Novel Mutation in FLNC (Filamin C) Causes Familial Restrictive Cardiomyopathy". Circ. Genom. Precis. Med. 2018, 11, e002117. [CrossRef]

106. Tucker, N.R.; McLellan, M.A.; Hu, D.; Ye, J.; Parsons, V.A.; Mills, R.W.; Clauss, S.; Dolmatova, E.; Shea, M.A.; Milan, D.J.; et al. Novel Mutation in FLNC (Filamin C) Causes Familial Restrictive Cardiomyopathy. Circ. Cardiovasc. Genet. 2017, 10, e001780. [CrossRef]

107. Rossi, D.; Palmio, J.; Evila, A.; Galli, L.; Barone, V.; Caldwell, T.A.; Policke, R.A.; Aldkheil, E.; Berndsen, C.E.; Wright, N.T.; et al. A novel FLNC frameshift and an OBSCN variant in a family with distal muscular dystrophy. PLoS ONE 2017, 12, e0186642. [CrossRef]

108. Jin, S.C.; Homsy, J.; Zaidi, S.; Lu, Q.; Morton, S.; DePalma, S.R.; Zeng, X.; Qi, H.; Chang, W.; Sierant, M.C.; et al. Contribution of rare inherited and de novo variants in 2,871 congenital heart disease probands. Nat. Genet. 2017, 49, 1593-1601. [CrossRef]

109. Janin, A.; N'Guyen, K.; Habib, G.; Dauphin, C.; Chanavat, V.; Bouvagnet, P.; Eschalier, R.; Streichenberger, N.; Chevalier, P.; Millat, G. Truncating mutations on myofibrillar myopathies causing genes as prevalent molecular explanations on patients with dilated cardiomyopathy. Clin. Genet. 2017, 92, 616-623. [CrossRef]

110. Van den Bogaart, F.J.; Claeys, K.G.; Kley, R.A.; Kusters, B.; Schrading, S.; Kamsteeg, E.J.; Voermans, N.C. Widening the spectrum of filamin-C myopathy: Predominantly proximal myopathy due to the p.A193T mutation in the actin-binding domain of FLNC. Neuromuscul. Disord. 2017, 27, 73-77. [CrossRef]

111. Gomez, J.; Lorca, R.; Reguero, J.R.; Moris, C.; Martin, M.; Tranche, S.; Alonso, B.; Iglesias, S.; Alvarez, V.; Diaz-Molina, B.; et al. Screening of the Filamin C Gene in a Large Cohort of Hypertrophic Cardiomyopathy Patients. Circ. Cardiovasc. Genet. 2017, 10, e001584. [CrossRef]

112. Ortiz-Genga, M.F.; Cuenca, S.; Dal Ferro, M.; Zorio, E.; Salgado-Aranda, R.; Climent, V.; Padron-Barthe, L.; Duro-Aguado, I.; Jimenez-Jaimez, J.; Hidalgo-Olivares, V.M.; et al. Truncating FLNC Mutations Are Associated with High-Risk Dilated and Arrhythmogenic Cardiomyopathies. J. Am. Coll. Cardiol. 2016, 68, 2440-2451. [CrossRef]

113. Begay, R.L.; Tharp, C.A.; Martin, A.; Graw, S.L.; Sinagra, G.; Miani, D.; Sweet, M.E.; Slavov, D.B.; Stafford, N.; Zeller, M.J.; et al. FLNC Gene Splice Mutations Cause Dilated Cardiomyopathy. JACC Basic Transl. Sci. 2016, 1, 344-359. [CrossRef]

114. Avila-Smirnow, D.; Gueneau, L.; Batonnet-Pichon, S.; Delort, F.; Becane, H.M.; Claeys, K.; Beuvin, M.; Goudeau, B.; Jais, J.P.; Nelson, I.; et al. Cardiac arrhythmia and late-onset muscle weakness caused by a myofibrillar myopathy with unusual histopathological features due to a novel missense mutation in FLNC. Rev. Neurol. (Paris) 2016, 172, 594-606. [CrossRef]

115. Reinstein, E.; Gutierrez-Fernandez, A.; Tzur, S.; Bormans, C.; Marcu, S.; Tayeb-Fligelman, E.; Vinkler, C.; Raas-Rothschild, A.; Irge, D.; Landau, M.; et al. Congenital dilated cardiomyopathy caused by biallelic mutations in Filamin C. Eur. J. Hum. Genet. 2016, 24, 1792-1796. [CrossRef]

116. Brodehl, A.; Ferrier, R.A.; Hamilton, S.J.; Greenway, S.C.; Brundler, M.A.; Yu, W.; Gibson, W.T.; McKinnon, M.L.; McGillivray, B.; Alvarez, N.; et al. Mutations in FLNC are Associated with Familial Restrictive Cardiomyopathy. Hum. Mutat. 2016, 37, 269-279. [CrossRef]

117. Evila, A.; Arumilli, M.; Udd, B.; Hackman, P. Targeted next-generation sequencing assay for detection of mutations in primary myopathies. Neuromuscul. Disord. 2016, 26, 7-15. [CrossRef]

118. Dai, Y.; Wei, X.; Zhao, Y.; Ren, H.; Lan, Z.; Yang, Y.; Chen, L.; Cui, L. A comprehensive genetic diagnosis of Chinese muscular dystrophy and congenital myopathy patients by targeted next-generation sequencing. Neuromuscul. Disord. 2015, 25, 617-624. [CrossRef]

119. Deo, R.C.; Musso, G.; Tasan, M.; Tang, P.; Poon, A.; Yuan, C.; Felix, J.F.; Vasan, R.S.; Beroukhim, R.; De Marco, T.; et al. Prioritizing causal disease genes using unbiased genomic features. Genome Biol. 2014, 15, 534. [CrossRef] 
120. Janssens, J.; Philtjens, S.; Kleinberger, G.; Van Mossevelde, S.; van der Zee, J.; Cacace, R.; Engelborghs, S.; Sieben, A.; Banzhaf-Strathmann, J.; Dillen, L.; et al. Investigating the role of filamin C in Belgian patients with frontotemporal dementia linked to GRN deficiency in FTLD-TDP brains. Acta Neuropathol. Commun. 2015, 3, 68. [CrossRef]

121. Valdes-Mas, R.; Gutierrez-Fernandez, A.; Gomez, J.; Coto, E.; Astudillo, A.; Puente, D.A.; Reguero, J.R.; Alvarez, V.; Moris, C.; Leon, D.; et al. Mutations in filamin C cause a new form of familial hypertrophic cardiomyopathy. Nat. Commun. 2014, 5, 5326. [CrossRef]

122. Tasca, G.; Odgerel, Z.; Monforte, M.; Aurino, S.; Clarke, N.F.; Waddell, L.B.; Udd, B.; Ricci, E.; Goldfarb, L.G. Novel FLNC mutation in a patient with myofibrillar myopathy in combination with late-onset cerebellar ataxia. Muscle Nerve 2012, 46, 275-282. [CrossRef] [PubMed]

123. Guergueltcheva, V.; Peeters, K.; Baets, J.; Ceuterick-de Groote, C.; Martin, J.J.; Suls, A.; De Vriendt, E.; Mihaylova, V.; Chamova, T.; Almeida-Souza, L.; et al. Distal myopathy with upper limb predominance caused by filamin C haploinsufficiency. Neurology 2011, 77, 2105-2114. [CrossRef] [PubMed]

124. Duff, R.M.; Tay, V.; Hackman, P.; Ravenscroft, G.; McLean, C.; Kennedy, P.; Steinbach, A.; Schoffler, W.; van der Ven, P.F.M.; Furst, D.O.; et al. Mutations in the N-terminal actin-binding domain of filamin C cause a distal myopathy. Am. J. Hum. Genet. 2011, 88, 729-740. [CrossRef]

125. Luan, X.; Hong, D.; Zhang, W.; Wang, Z.; Yuan, Y. A novel heterozygous deletion-insertion mutation (2695-2712 del/GTTTGT ins) in exon 18 of the filamin C gene causes filaminopathy in a large Chinese family. Neuromuscul. Disord. 2010, 20, 390-396. [CrossRef]

126. Shatunov, A.; Olive, M.; Odgerel, Z.; Stadelmann-Nessler, C.; Irlbacher, K.; van Landeghem, F.; Bayarsaikhan, M.; Lee, H.S.; Goudeau, B.; Chinnery, P.F.; et al. In-frame deletion in the seventh immunoglobulin-like repeat of filamin C in a family with myofibrillar myopathy. Eur. J. Hum. Genet. 2009, 17, 656-663. [CrossRef]

127. Vorgerd, M.; van der Ven, P.F.; Bruchertseifer, V.; Lowe, T.; Kley, R.A.; Schroder, R.; Lochmuller, H.; Himmel, M.; Koehler, K.; Furst, D.O.; et al. A mutation in the dimerization domain of filamin c causes a novel type of autosomal dominant myofibrillar myopathy. Am. J. Hum. Genet. 2005, 77, 297-304. [CrossRef]

128. Kley, R.A.; Hellenbroich, Y.; van der Ven, P.F.; Furst, D.O.; Huebner, A.; Bruchertseifer, V.; Peters, S.A.; Heyer, C.M.; Kirschner, J.; Schroder, R.; et al. Clinical and morphological phenotype of the filamin myopathy: A study of 31 German patients. Brain 2007, 130, 3250-3264. [CrossRef]

129. Goldfarb, L.G.; Park, K.Y.; Cervenakova, L.; Gorokhova, S.; Lee, H.S.; Vasconcelos, O.; Nagle, J.W.; Semino-Mora, C.; Sivakumar, K.; Dalakas, M.C. Missense mutations in desmin associated with familial cardiac and skeletal myopathy. Nat. Genet. 1998, 19, 402-403. [CrossRef]

130. Vicart, P.; Caron, A.; Guicheney, P.; Li, Z.; Prevost, M.C.; Faure, A.; Chateau, D.; Chapon, F.; Tome, F.; Dupret, J.M.; et al. A missense mutation in the alphaB-crystallin chaperone gene causes a desmin-related myopathy. Nat. Genet. 1998, 20, 92-95. [CrossRef]

131. Hauser, M.A.; Horrigan, S.K.; Salmikangas, P.; Torian, U.M.; Viles, K.D.; Dancel, R.; Tim, R.W.; Taivainen, A.; Bartoloni, L.; Gilchrist, J.M.; et al. Myotilin is mutated in limb girdle muscular dystrophy 1A. Hum. Mol. Genet. 2000, 9, 2141-2147. [CrossRef]

132. Selcen, D.; Engel, A.G. Mutations in ZASP define a novel form of muscular dystrophy in humans. Ann. Neurol. 2005, 57, 269-276. [CrossRef]

133. Selcen, D.; Muntoni, F.; Burton, B.K.; Pegoraro, E.; Sewry, C.; Bite, A.V.; Engel, A.G. Mutation in BAG3 causes severe dominant childhood muscular dystrophy. Ann. Neurol. 2009, 65, 83-89. [CrossRef]

134. Gialluisi, A.; Newbury, D.F.; Wilcutt, E.G.; Olson, R.K.; DeFries, J.C.; Brandler, W.M.; Pennington, B.F.; Smith, S.D.; Scerri, T.S.; Simpson, N.H.; et al. Genome-wide screening for DNA variants associated with reading and language traits. Genes Brain Behav. 2014, 13, 686-701. [CrossRef]

135. Wilkinson, J.D.; Westphal, J.A.; Bansal, N.; Czachor, J.D.; Razoky, H.; Lipshultz, S.E. Lessons learned from the Pediatric Cardiomyopathy Registry (PCMR) Study Group. Cardiol. Young 2015, 25 (Suppl. 2), 140-153. [CrossRef]

136. Golbus, J.R.; Puckelwartz, M.J.; Dellefave-Castillo, L.; Fahrenbach, J.P.; Nelakuditi, V.; Pesce, L.L.; Pytel, P.; McNally, E.M. Targeted analysis of whole genome sequence data to diagnose genetic cardiomyopathy. Circ. Cardiovasc. Genet. 2014, 7, 751-759. [CrossRef] 
137. Lowe, T.; Kley, R.A.; van der Ven, P.F.; Himmel, M.; Huebner, A.; Vorgerd, M.; Furst, D.O. The pathomechanism of filaminopathy: Altered biochemical properties explain the cellular phenotype of a protein aggregation myopathy. Hum. Mol. Genet. 2007, 16, 1351-1358. [CrossRef]

138. Kley, R.A.; Serdaroglu-Oflazer, P.; Leber, Y.; Odgerel, Z.; van der Ven, P.F.; Olive, M.; Ferrer, I.; Onipe, A.; Mihaylov, M.; Bilbao, J.M.; et al. Pathophysiology of protein aggregation and extended phenotyping in filaminopathy. Brain 2012, 135, 2642-2660. [CrossRef]

139. Haataja, T.J.K.; Capoulade, R.; Lecointe, S.; Hellman, M.; Merot, J.; Permi, P.; Pentikainen, U. Critical Structural Defects Explain Filamin A Mutations Causing Mitral Valve Dysplasia. Biophys. J. 2019, 117, 1467-1475. [CrossRef]

140. Reimann, L.; Wiese, H.; Leber, Y.; Schwable, A.N.; Fricke, A.L.; Rohland, A.; Knapp, B.; Peikert, C.D.; Drepper, F.; van der Ven, P.F.; et al. Myofibrillar Z-discs Are a Protein Phosphorylation Hot Spot with Protein Kinase C (PKCalpha) Modulating Protein Dynamics. Mol. Cell. Proteom. 2017, 16, 346-367. [CrossRef]

141. Prill, K.; Dawson, J.F. Assembly and Maintenance of Sarcomere Thin Filaments and Associated Diseases. Int. J. Mol. Sci. 2020, 21, 542. [CrossRef]

142. Lemke, S.B.; Schnorrer, F. Mechanical forces during muscle development. Mech. Dev. 2017, 144, 92-101. [CrossRef]

143. Knoll, R.; Buyandelger, B.; Lab, M. The sarcomeric Z-disc and Z-discopathies. J. Biomed. Biotechnol. 2011, 2011, 569628. [CrossRef]

144. Rognoni, L.; Stigler, J.; Pelz, B.; Ylanne, J.; Rief, M. Dynamic force sensing of filamin revealed in single-molecule experiments. Proc. Natl. Acad. Sci. USA 2012, 109, 19679-19684. [CrossRef]

145. Kishino, A.; Yanagida, T. Force measurements by micromanipulation of a single actin filament by glass needles. Nature 1988, 334, 74-76. [CrossRef]

146. Nishizaka, T.; Miyata, H.; Yoshikawa, H.; Ishiwata, S.; Kinosita, K., Jr. Unbinding force of a single motor molecule of muscle measured using optical tweezers. Nature 1995, 377, 251-254. [CrossRef]

147. Chen, H.; Zhu, X.; Cong, P.; Sheetz, M.P.; Nakamura, F.; Yan, J. Differential mechanical stability of filamin A rod segments. Biophys. J. 2011, 101, 1231-1237. [CrossRef]

148. Chen, H.; Chandrasekar, S.; Sheetz, M.P.; Stossel, T.P.; Nakamura, F.; Yan, J. Mechanical perturbation of filamin A immunoglobulin repeats 20-21 reveals potential non-equilibrium mechanochemical partner binding function. Sci. Rep. 2013, 3, 1642. [CrossRef]

149. Xu, T.; Lannon, H.; Wolf, S.; Nakamura, F.; Brujic, J. Domain-domain interactions in filamin A (16-23) impose a hierarchy of unfolding forces. Biophys. J. 2013, 104, 2022-2030. [CrossRef]

150. Ferrer, J.M.; Lee, H.; Chen, J.; Pelz, B.; Nakamura, F.; Kamm, R.D.; Lang, M.J. Measuring molecular rupture forces between single actin filaments and actin-binding proteins. Proc. Natl. Acad. Sci. USA 2008, 105, 9221-9226. [CrossRef]

151. Molloy, J.E.; Burns, J.E.; Kendrick-Jones, J.; Tregear, R.T.; White, D.C. Movement and force produced by a single myosin head. Nature 1995, 378, 209-212. [CrossRef]

152. Finer, J.T.; Simmons, R.M.; Spudich, J.A. Single myosin molecule mechanics: Piconewton forces and nanometre steps. Nature 1994, 368, 113-119. [CrossRef]

153. Haataja, T.J.K.; Bernardi, R.C.; Lecointe, S.; Capoulade, R.; Merot, J.; Pentikainen, U. Non-syndromic Mitral Valve Dysplasia Mutation Changes the Force Resilience and Interaction of Human Filamin A. Structure 2019, 27, 102-112.e4. [CrossRef]

(C) 2020 by the authors. Licensee MDPI, Basel, Switzerland. This article is an open access article distributed under the terms and conditions of the Creative Commons Attribution (CC BY) license (http://creativecommons.org/licenses/by/4.0/). 